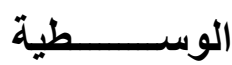

إعداد

علي عبدالجليل السيد الثوني

تخصص در اسات إسلامية بقسم اللغة العربية ـ كلية الآداب - جامعة طنطا

أ.د. أماني كمال غريب

أستاذ الدر اسات الإسلامية بكلية الآداب - جامعة طنطا لئل

د. ديبعي محمد عبدالخالق

مدرس الأدب المتفرغ بكلية الآداب - جامعة طنطا

المستخلص:

جاء هذا البحث بعنوان الوسطية، ويُيرز هذا البحث وسطية الإسلام، وأنه حريص على إبعاد

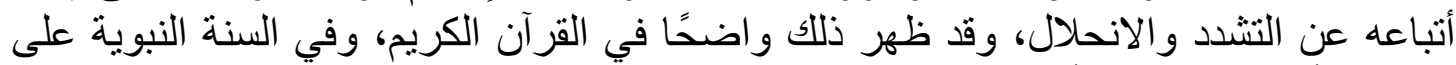
صاحبها أفضل الصناة و أتم السلام. وقد اثتمل هذا البحث على تعريف بحقيقة الوسطية في اللغة، وإطلاقاتها في القرآن الكريم، وبيان للوسطية الموجودة في القراءات القر آنية، و هذه الوسطية التي دلت عليها القر اءات القرآنية موجودة في القو اعد والأصول مثل: وسطية الاجتهاد، وموجودة في المفاهيم مثل مفهوم القتال.

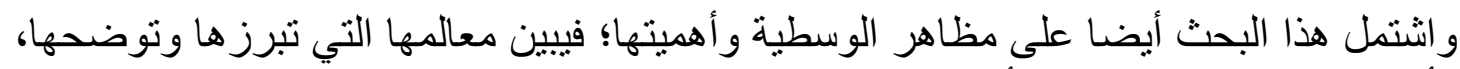

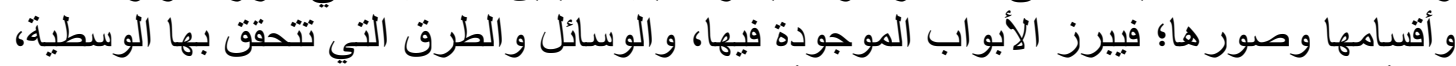

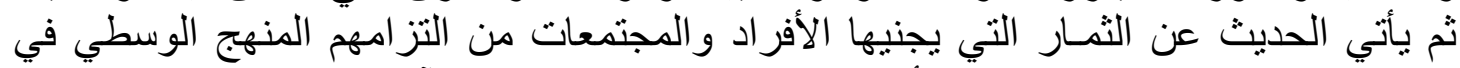

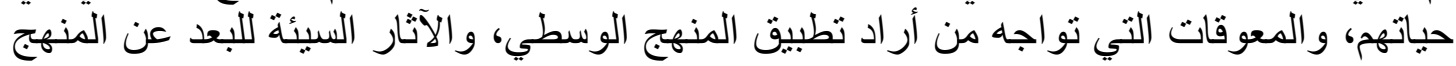

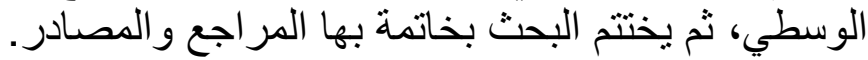

الكلمات الإفتتاحية: المعاجم، الأقسام، الوسائل، الثمار ، المعوقات 


\section{مقدمة}

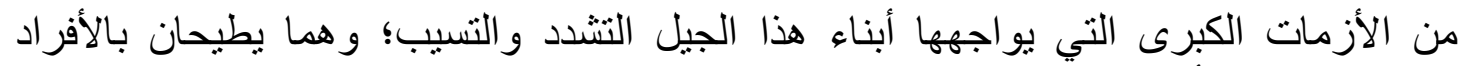

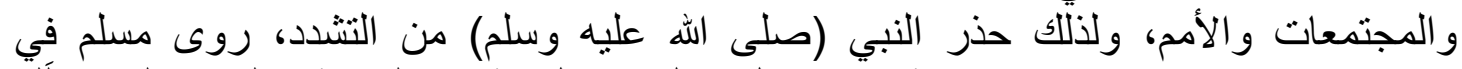

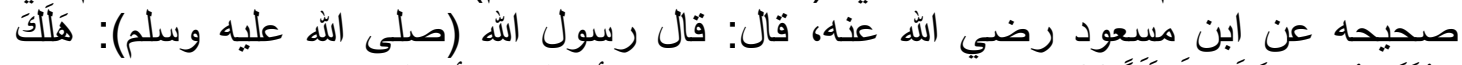

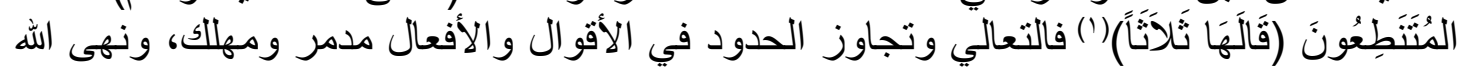

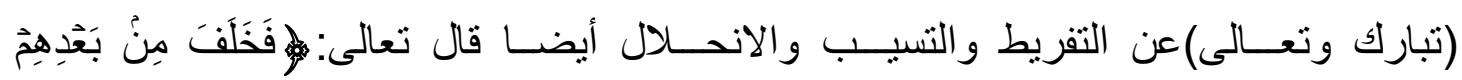

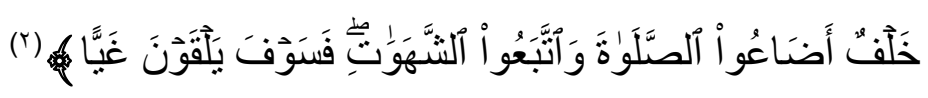

وإن من مميزات الإسلام وسطيتة، بلا إفراط و لا تفريط، وبهذه الوسطية استحقت الأمة أن

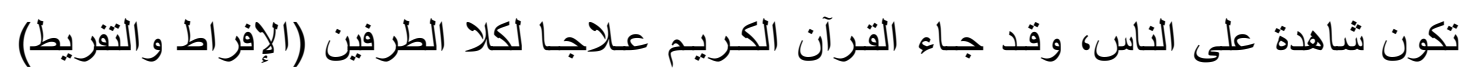

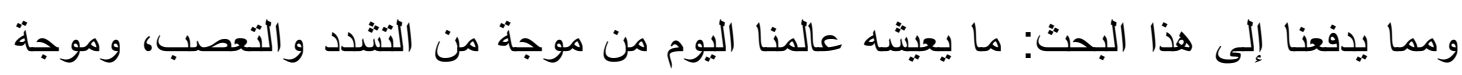
أخرى من الانحلال والتسيب، وفي هذا البحث: تعريف الوسطية، الوسطية في القراءات القرآنية، مظاهر الوسطية وأهميتها، أقسام الوسطية وصور ها، وسائل تحقيق الوسطية، ثمـار

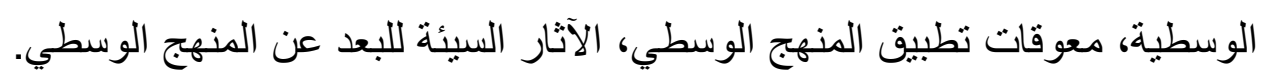

\section{أولاً: تعريف الوسطية}

الوسطية في اللغة

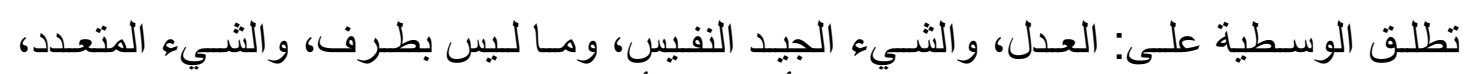

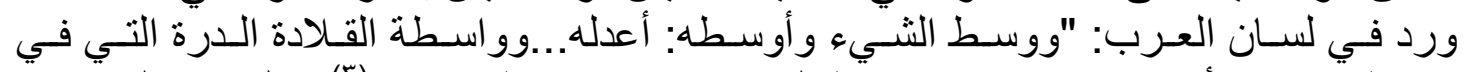

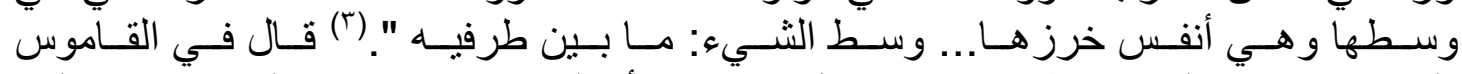

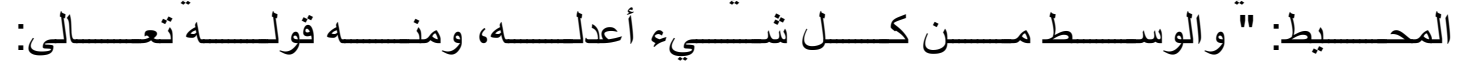

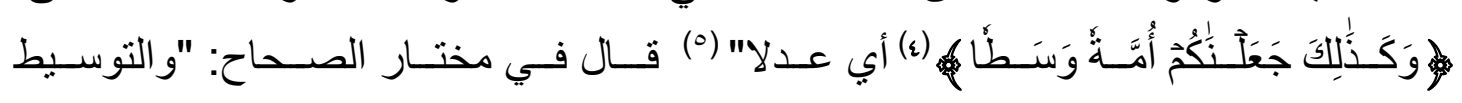
أيضا قطع الثيء نصفين و التوسط بين الناس من الوساطة". (†)

(- صحيح مسلم (المسند الصحيح المختصر بنقل العدل عن العدل إلى رسول الهه - صلى اله عليه وسلم-) مسلم

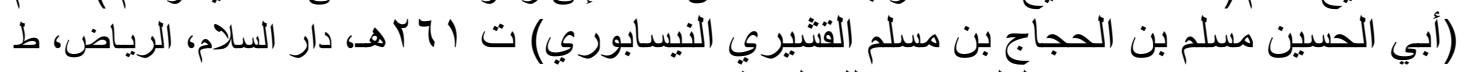

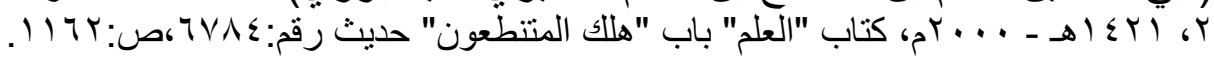

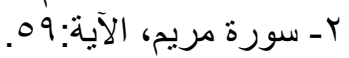

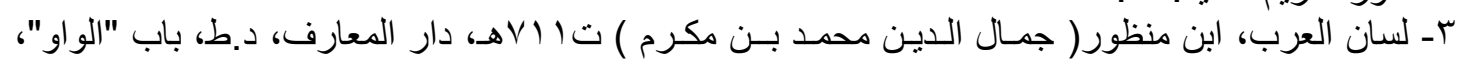

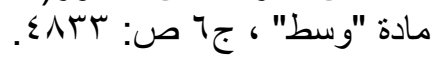

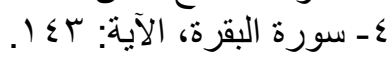

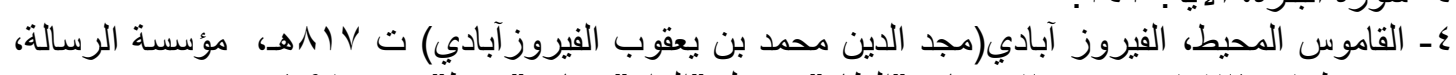

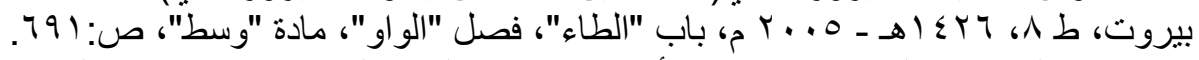

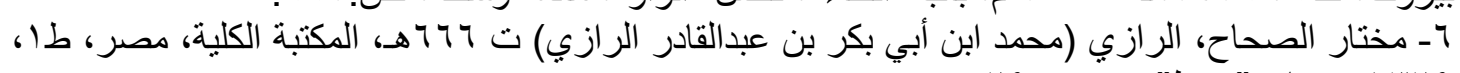

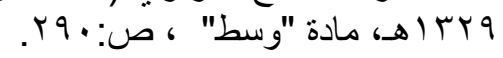


فالوسطية هي العدل الذي يقتضي عـدم التفريـق بين الثيء ونظئ ونظيره، و ألاّ يُكال بمكيالين،

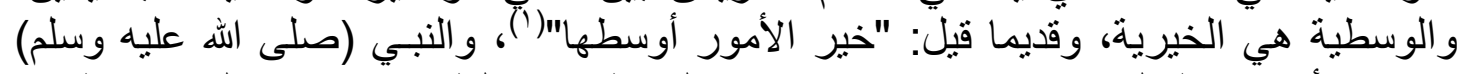

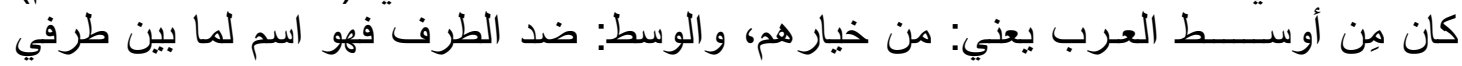

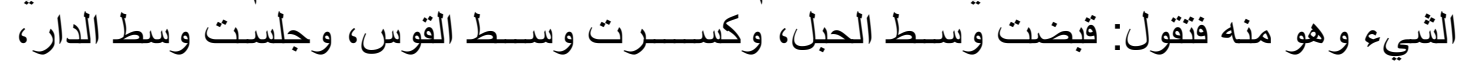
و الوسطية: التعددية، فقطع الثيء نصفين فيه تعدد، و الوساطة بين الناس لا تتم إلا باحتر ام كافة ولة الآراء.

$$
\text { الوسطية في الاصطلاح }
$$

الوســـية مصطلح حديث لكن معناها ومادتها موجودة في القرآن الكريم و السنة النبوية، لذلك نقدم أولاً بعض استخداماتها في القرآن الكريم، فقد استُخدمت في القرآن الكريم بمعان لا تبعد كثيراً عن المعاني اللغوية، فهي تدور حول العدل والتوازن الذي يقتضي أن يكون الإنسان في موقف معتدل بين طرفين.

استُخدمت هذه المادة في القرآن الكريم للالالة على شيء نفيس بين شيئين أوطرفيـن أو جانبين، و لا يشترط أن يكون هذان الطرفان مذمومين ولا أن يكون الوسط عند حدود النصف؛ لأن هذا أمـر يصــب تحديده في المعنويـات.

فقد يكون بين سيأين مذمومين ( إفر اط وتفريط، غلو وتقصير، تشدد وتميُّع، جمود و انحلال)

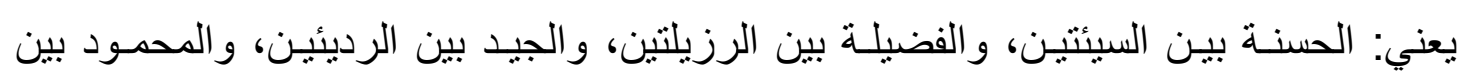

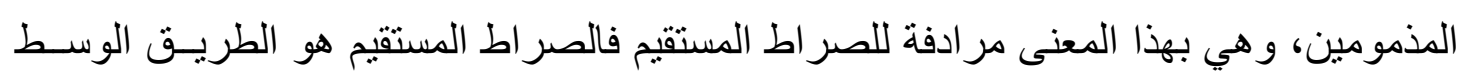
المعتدل بين طرفين أحدهما عرف الحق وتركه، والآخر لم يهتد للحق أصلا و ومنه قوله تعالى:

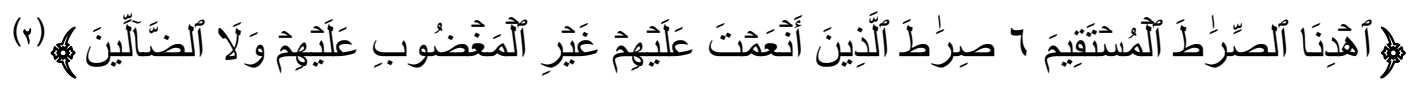
وقد يكون بين حسنين محمودين كصلاة العصر(r) ( فإنها بين الظهر و المغرب) قـال تعالى:

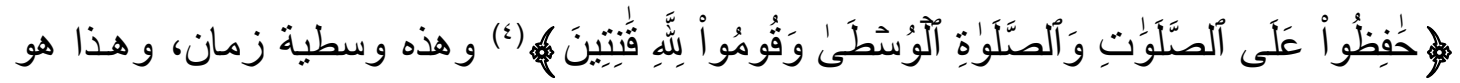
الأجود بين جنسه، ويُضرب له مَثل في المعاجم بوسط القلادة، وقد ذكر سابقاً، قال الإمام

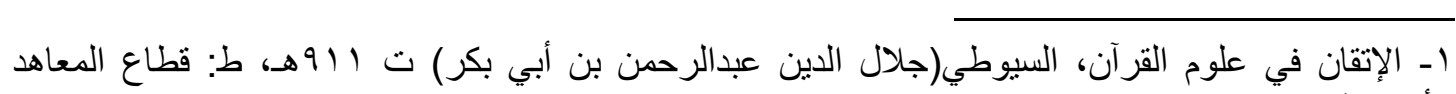

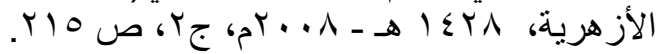

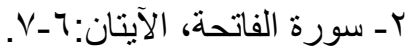

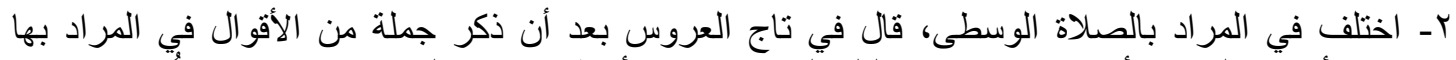

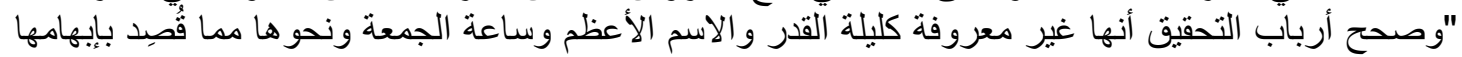

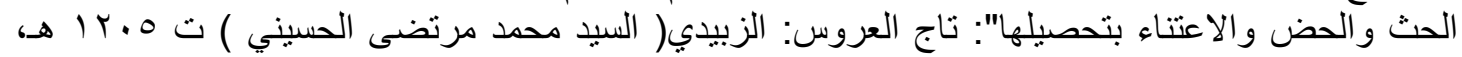

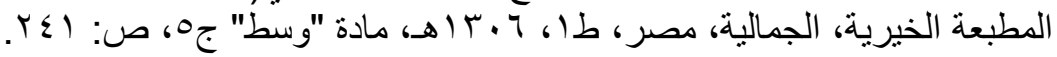

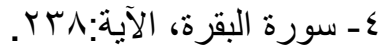


الطبري: "و الصواب من القول في ذلك ما تظاهرتٌْ به الأخبارُ عن رسول الله (صلى الله عليه

وسلم) هو أنها العصر" (1) (1)

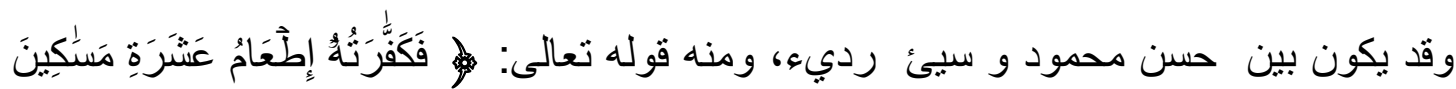

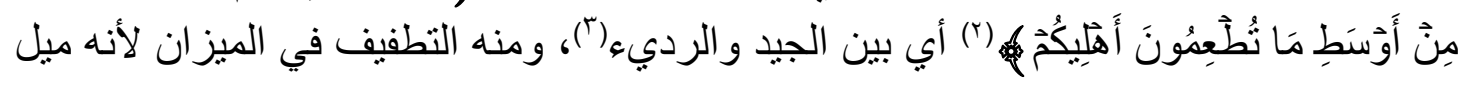

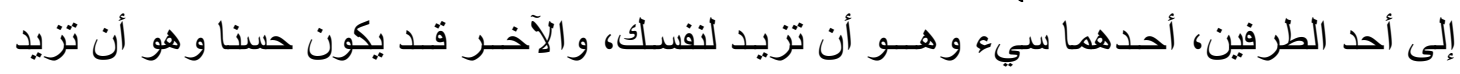

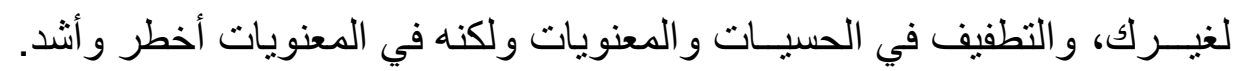

وقد لا يكون هذا الوسط بين شيئين و لا جانبين و لا طرفين فوسط الثيء أعلاه و أفضله، ومنه

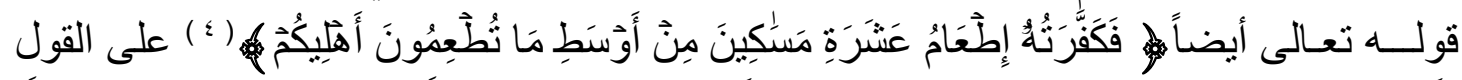

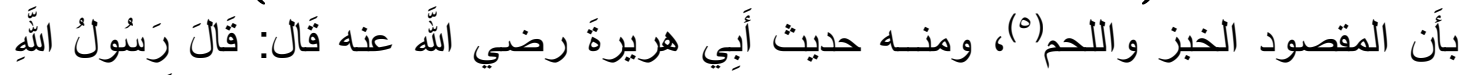

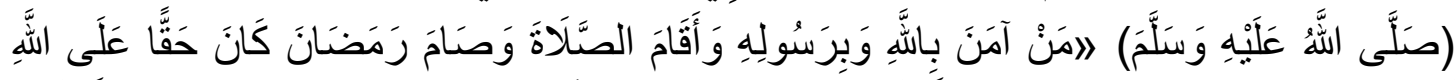

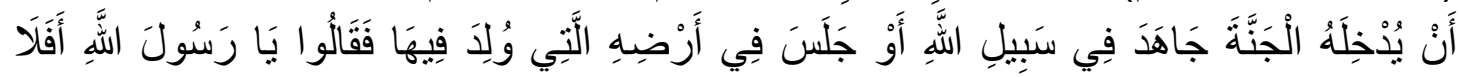

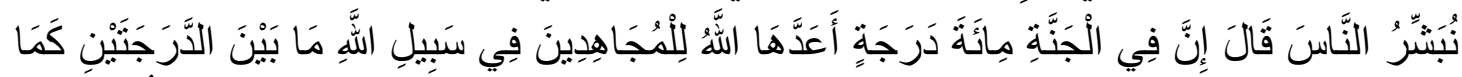

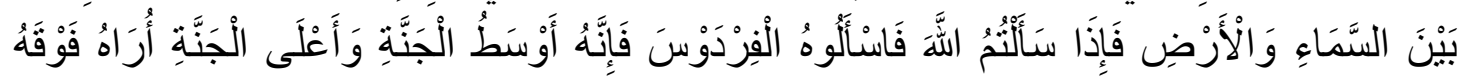

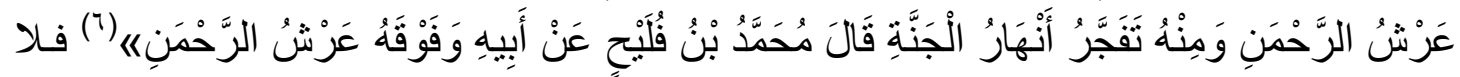

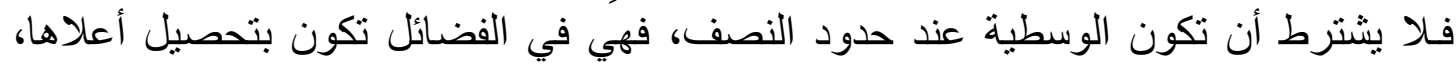

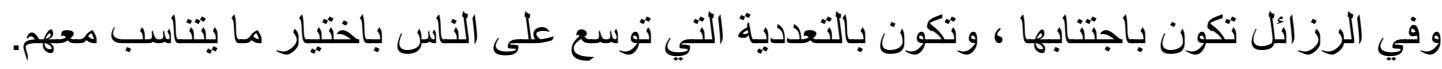

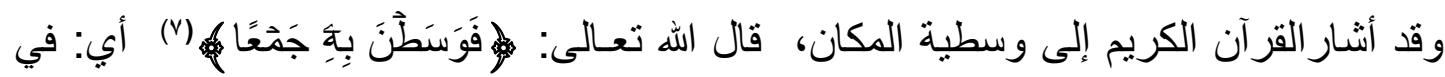

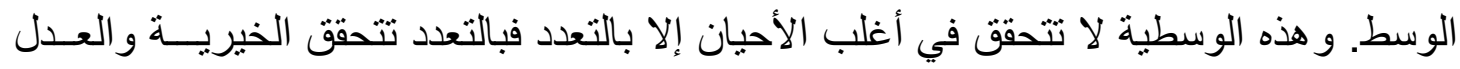

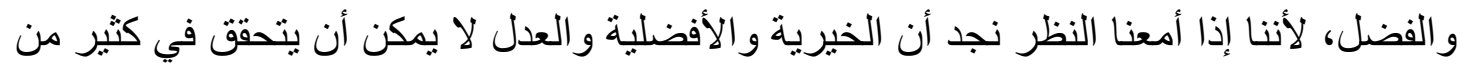

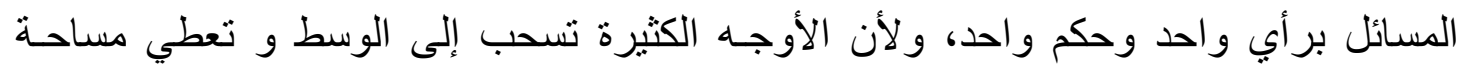

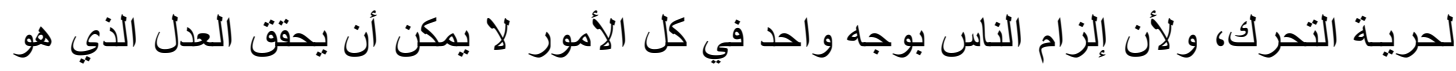

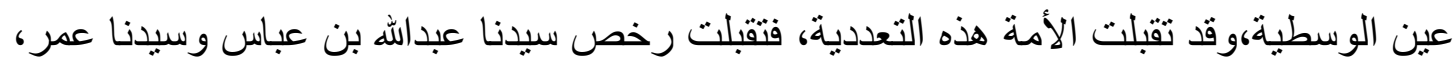

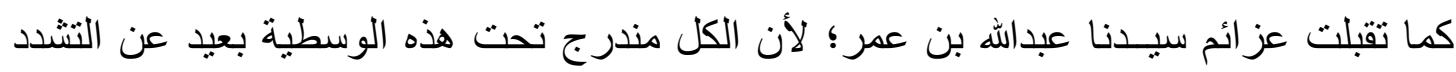

ا- جامع البيان عن تأويل آي القرآن، الطبري (أبو جعفر محمد بن جرير) ت . آآه، الرسالة، بيروت، طا، .91: 910

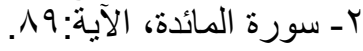

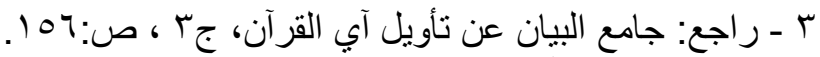

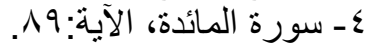

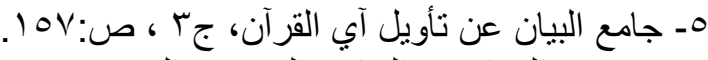

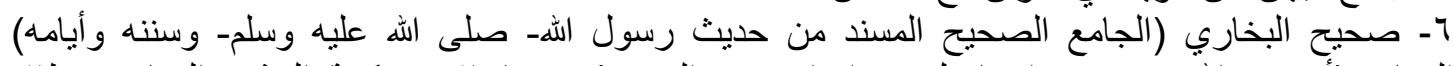

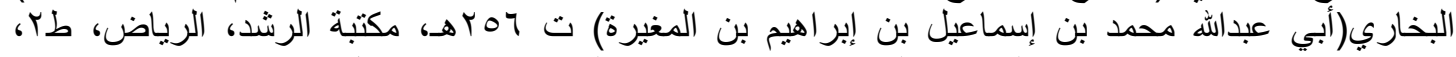

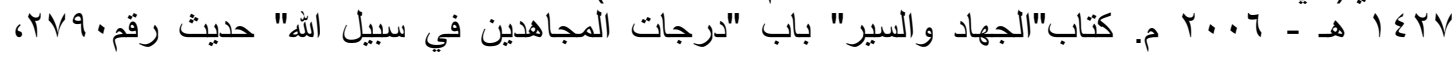


والانحلال، ويظهر من مجموع هذه المعاني أنَّ أقصى اليمين وأقصى اليسـار و الرؤيـة الأحاديــة و عدم الإيمان بالتتوع والتعددية كل هذا يتعارض مع الونطية الوسطية.

وبهذا يظهـر أنَّ مَن يُبرز أسـوأ مـا عند الطرف الآخَر ومَن يتعصب تعصباً أعمى

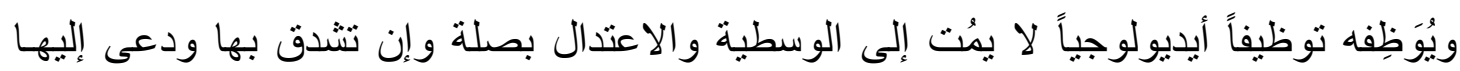

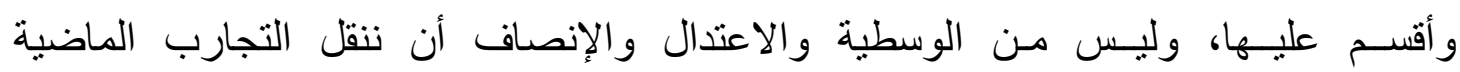
بمشاعر ها وأحاسيسها وملابساتها والظــروف المحيطة بها إلى واقع مغاير - بدرجة كبيرة لو اقعنا.

ويمكن تعريف الوسطيـة أيضـاً بأنها تصـور الإسـلام للمناهـج والمو اقف التي تواجه الإنسان باعتدال، والسعي لتحري الصواب دون تثدد أو انحلال لكن باختيار الحل الأوسط بينهما،

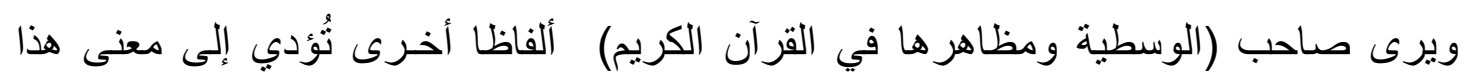

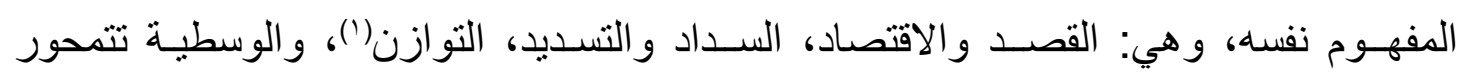

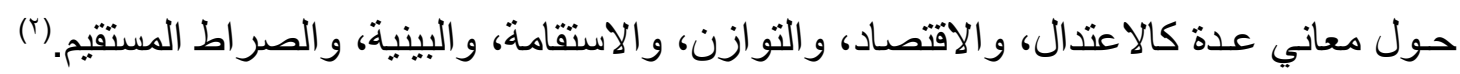

\section{مَ ثانياً: الوسطية في القراعات القر آنية}

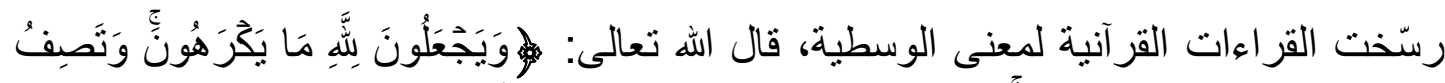

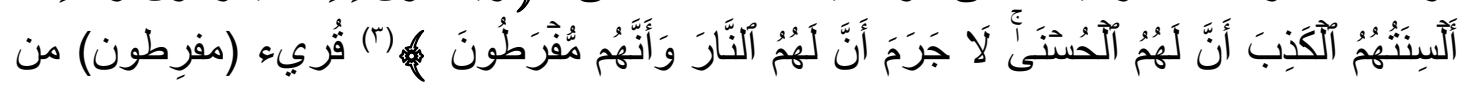

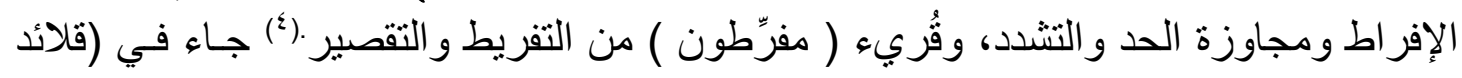

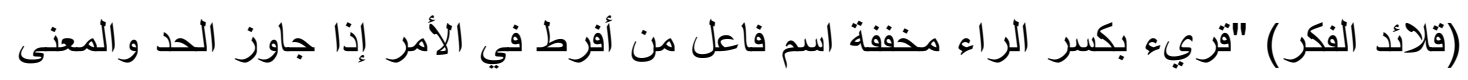

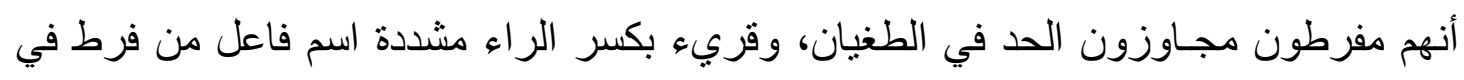

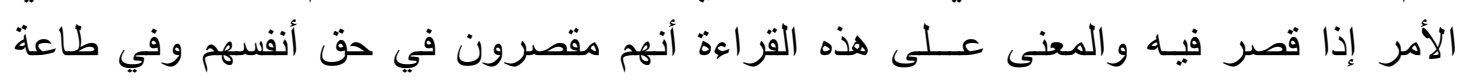

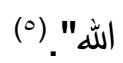

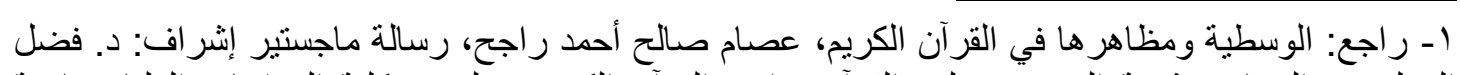

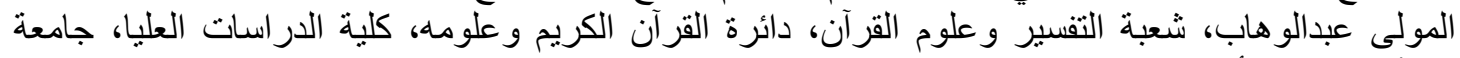

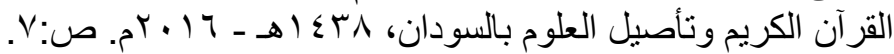

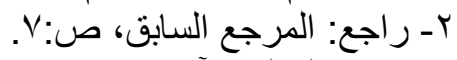

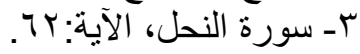

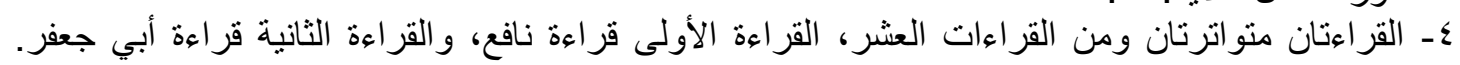

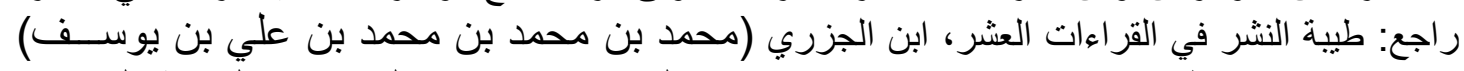

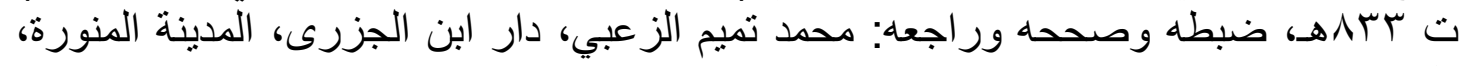

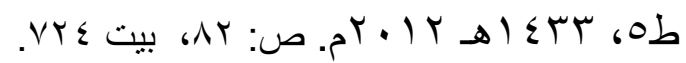

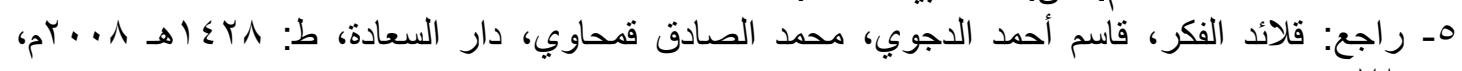
ص: 
و هذه الوسطية التي دلت عليها القراءات موجودة في القواعد والأصول مثل: وسطية الاجتهاد، وموجودة في المفاهيم مثل: مفهوم القتال.

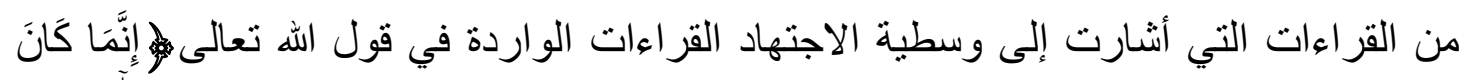

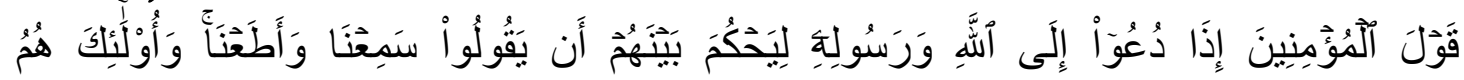

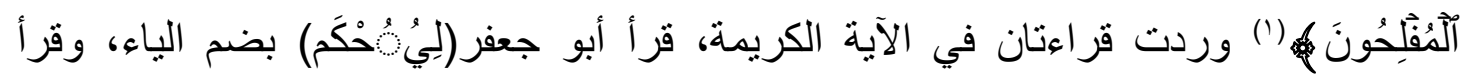

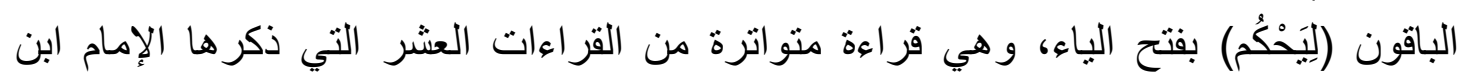

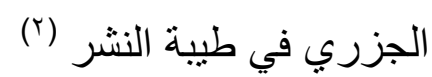

القراءة الأولى: ليُحكم - بالبناء للمفعول ـ فتحت باب الاجتهاد ووسَّعَت دائرة المجتهدين،

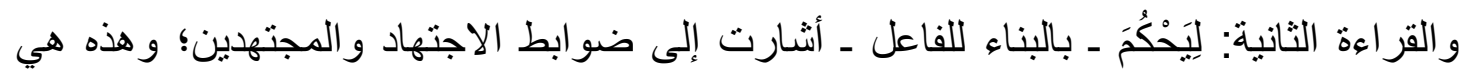
الوسطية أن يُفتح باب الاجتهاد بضو ابط.

القراءة الأولى رُو عِي فيها الحُكْم أكثر من مراعاة من سيقوم بالحُكْم، قال أبو حيان في البحر

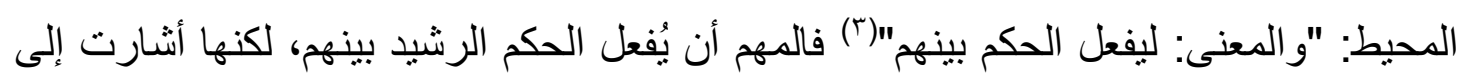

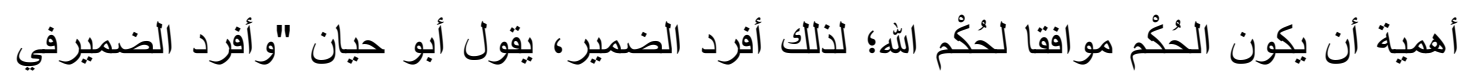

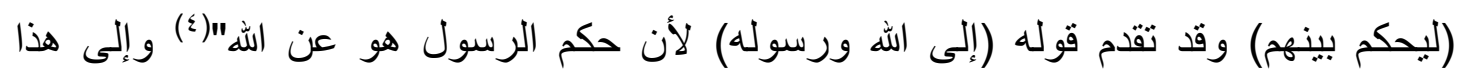
المعنى أثشار الزمخشري في الكثاف حيث قال: "فإن قلت: إلام أسند يحكم؟ ولان لان بد له له من فاعل.

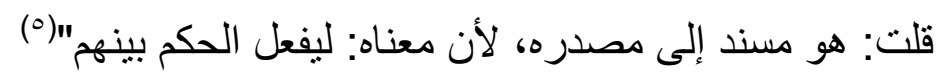

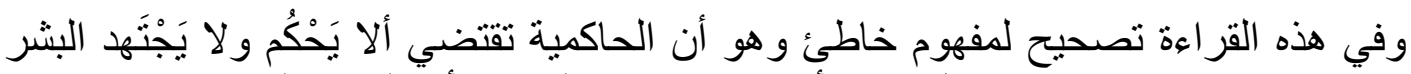

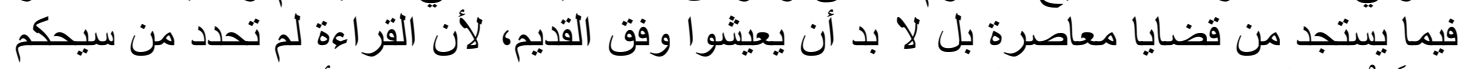

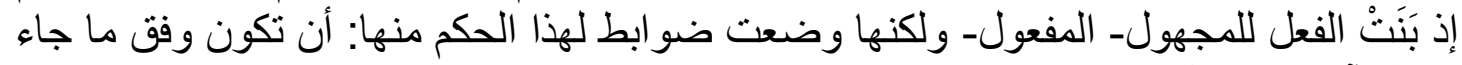

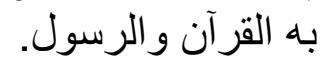

فالمر اد من الحاكمية هو وجود حكم عادل رشيد يحقق مصالح العباد و البلاد، وليس مجرد

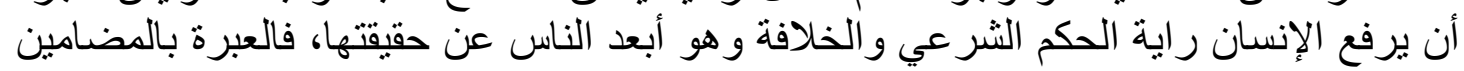

$$
\text { r- ا- سورة النور، الآية: } 01 .
$$

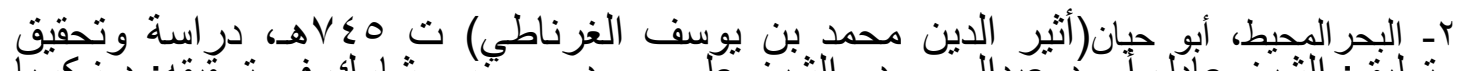

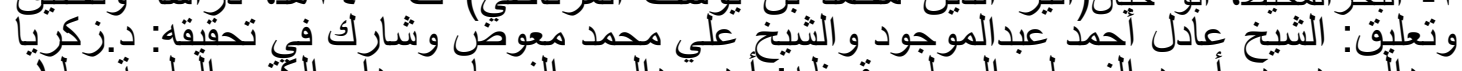

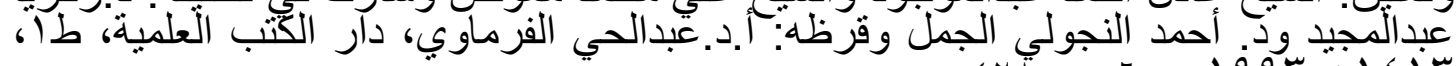
أ

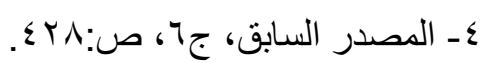

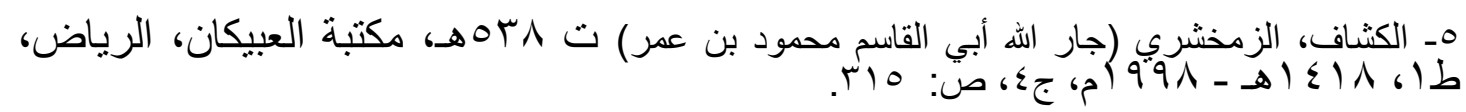


لا بالعناوين، وبالمسميات لا بالأسماء، والإسلام لم بضع قالبا جامدا لنظام الحكم ولم يُنَصِّب شخصا بعينه ليحكم و إنما وضع ضات لالابط تلتحقق بها مصالح البلاد و العباد.

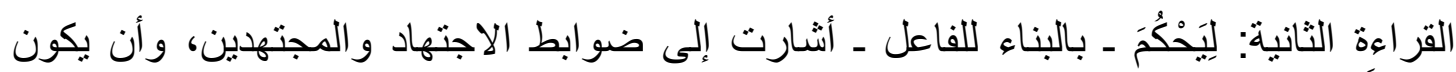
مو افقاً للقو اعد العامة في القرآن الكريم و السنة النبوية.

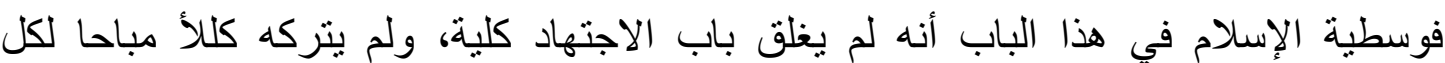

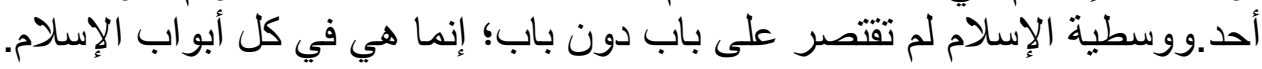

ومن القراءات التي رسخت للاجتهاد بوسطية واعتدال أيضا، القراءات الواردة في قول اله

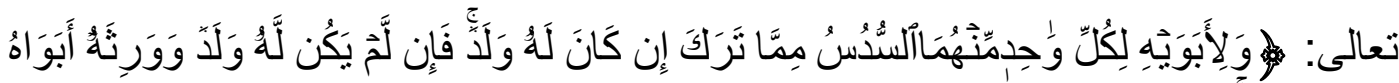

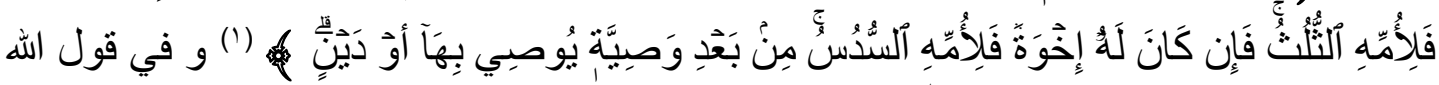

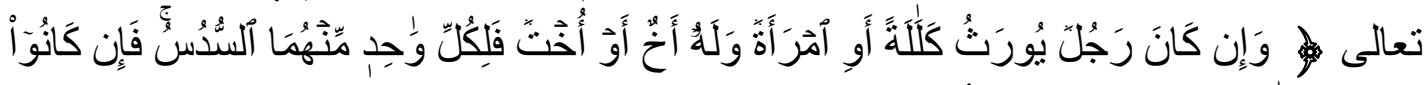

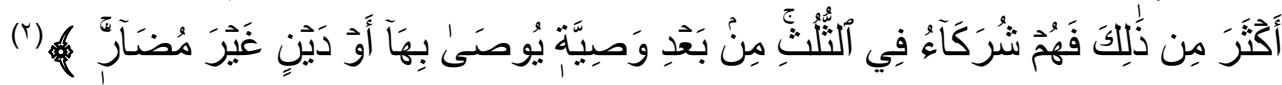
القراءات التي تدل على معنى الوسطية في الآيتين الكريمتين:

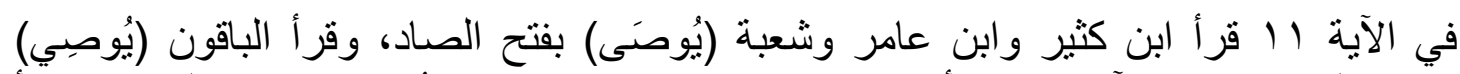

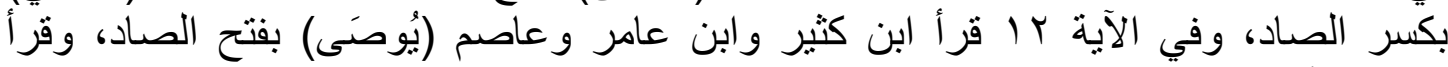

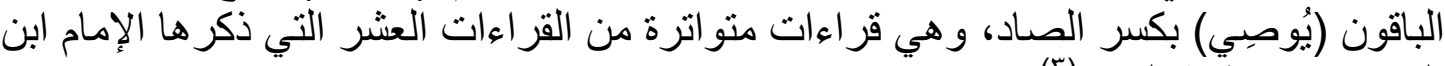

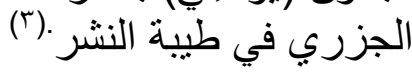

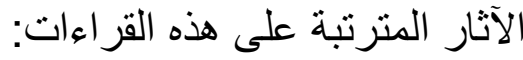

يوصي: بالبناء للمعلوم (الفاعل)، يوصنى: بالبناء للمجهول (المفعول)، والقراءتان تتكاملان في

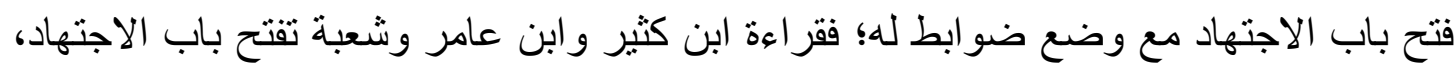
وقراءة الباقين تبين الأصل و الضابط. وبيان ذلك: قراءة البناء للمجهول (المفعول) لم تحدد من سَيْوَصِي فَفَتَحَت باب الاجتهاد في

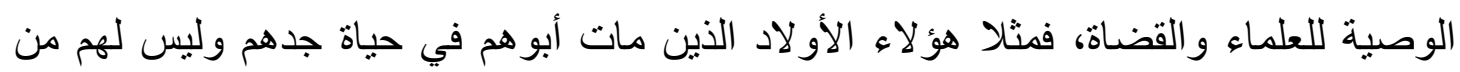

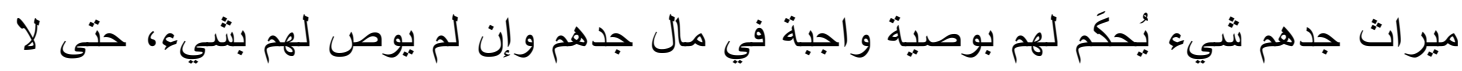

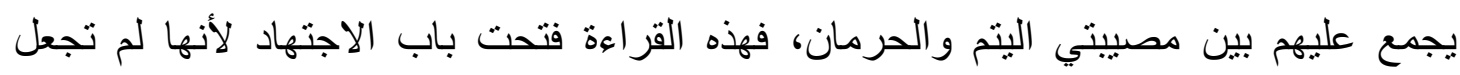
الوصية حق لصاحب المال فقط. فيؤخذ من قراءة البناء للمفعول أنه قد يوصي غير الميت، فيستفاد من هذه القراءة في فتح

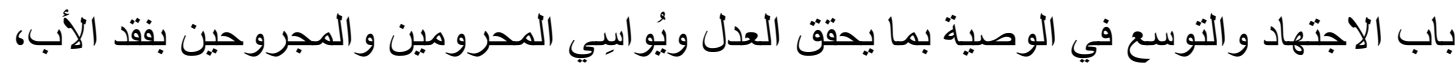


و إنما يؤخذ هذا الحكم من الآية (1) ولا يؤخذ من الآية (ب (1) لأن الآية (1) جاء التنبيه فيها

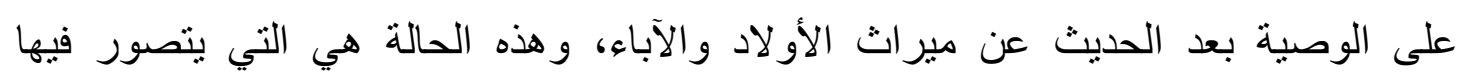

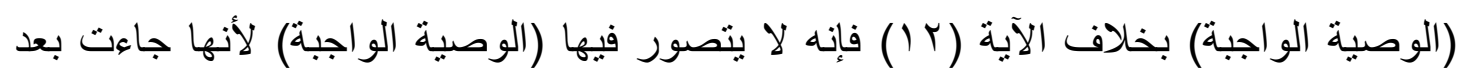

$$
\text { مير اث الإخوة لأم. }
$$

أما قر اءة البناء للمعلوم (الفاعل) فهي بيان للأصل قال أبو حيان: "و المعنى: من بعد وصية

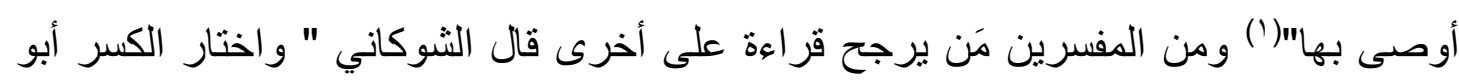

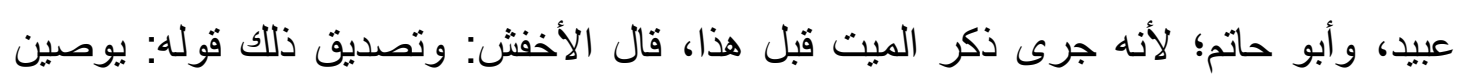

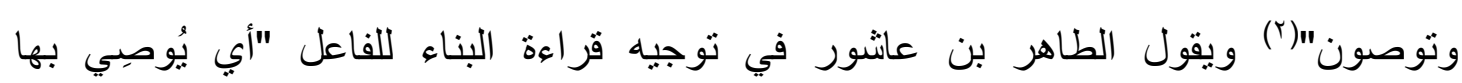

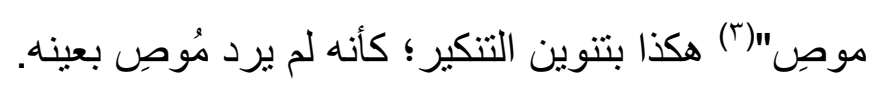

ومن القراءات التي أشارت إلى الوسطية في مفهوم القتال القراءات الواردة في قول الله

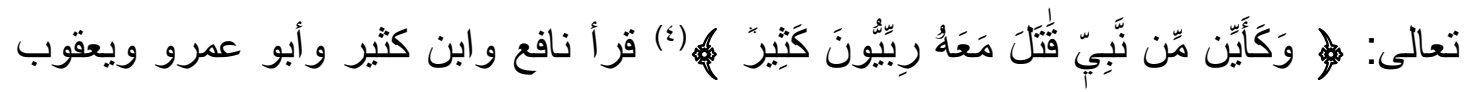

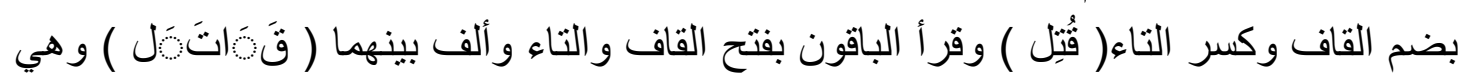

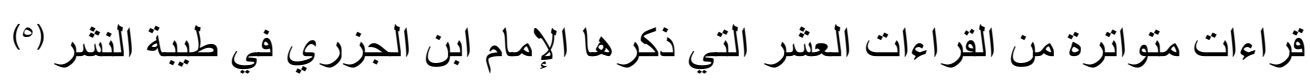
قر اءة (قَاتل) تعالج التقصير ، وقر اءة (قُتل) تعالج الغلو ؛ فيكون المعنى من مجموع القر اءتين معنى وسطي لا إفر اط فيه و لاتفريط. ولتوضيح ذلك نقول: قراءة ( قاتل ) فيها مفاعلة ومشاركة، ورد في لسان العرب: "وسبيل

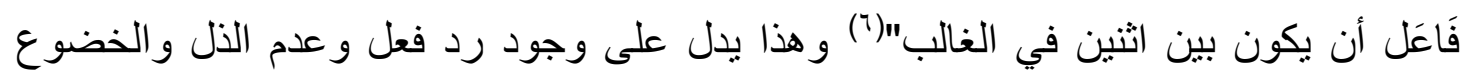

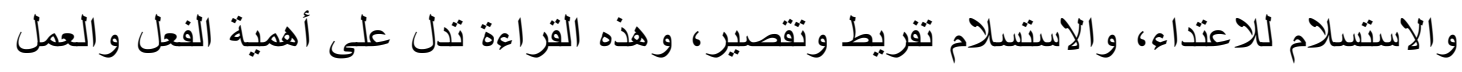

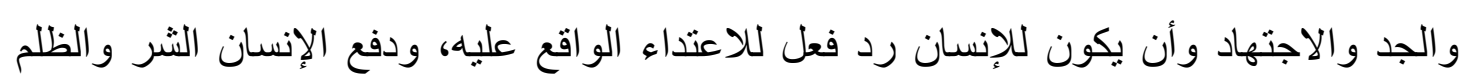

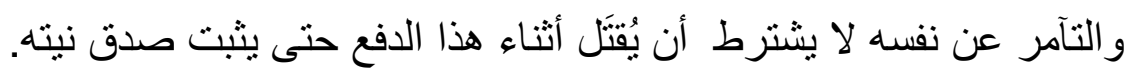

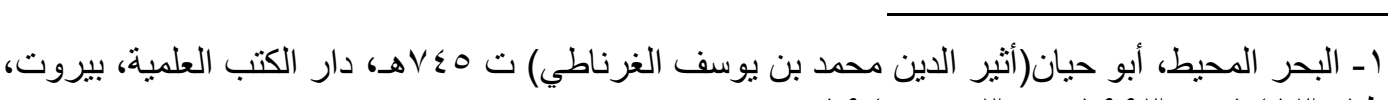

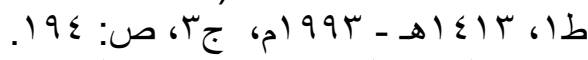

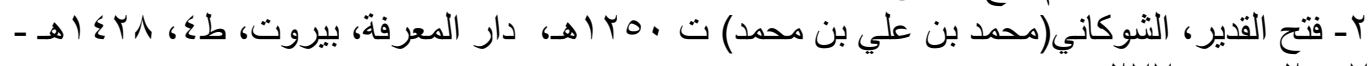

$$
\begin{aligned}
& \text { TVV }
\end{aligned}
$$

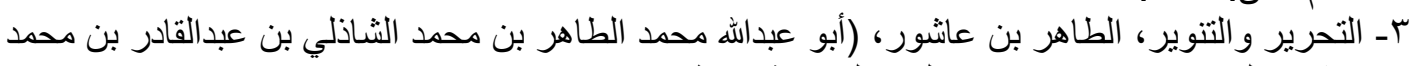

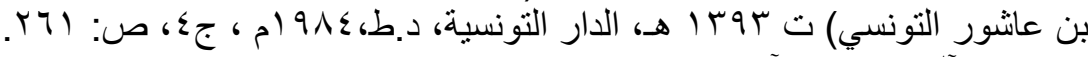

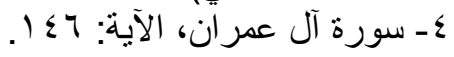

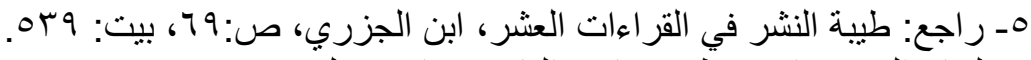

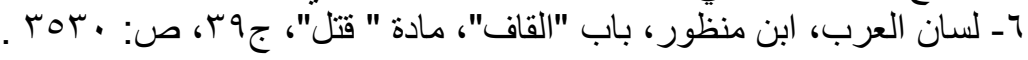


أما قراءة ( قُتل ) فهي تدل على عدم الاعتداء، فإن القاتل ـ في الغالب ـ معتدي، والمقتول

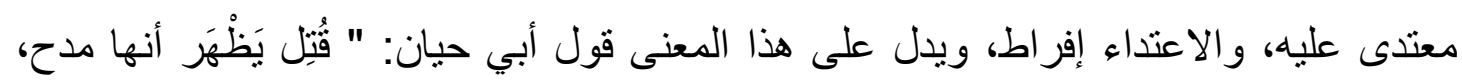

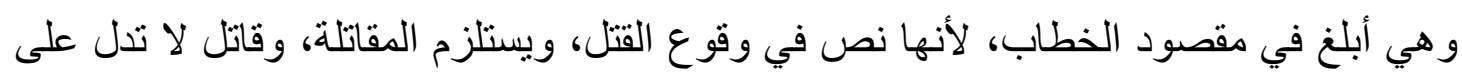

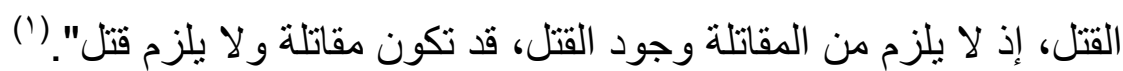
بينما يرى الثعالبي أن (قاتل) أعم في المدح يقول "وحجة من قرأ (قاتل): أنها أعم في المدح؛

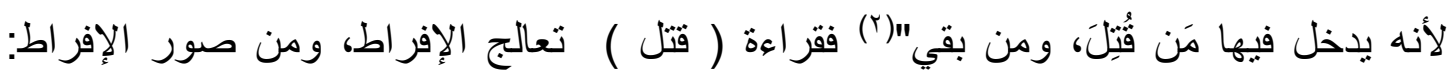

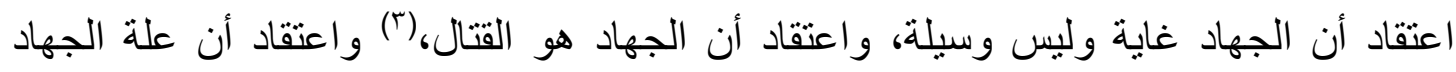

و علة الجهاد الاعتداء و التآمر وليس الكفر بدليل أن القرآن الكريم صرح بأن العلة من القتال

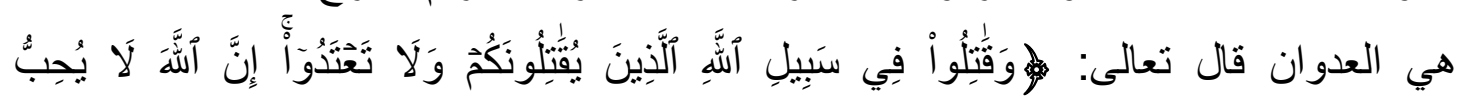

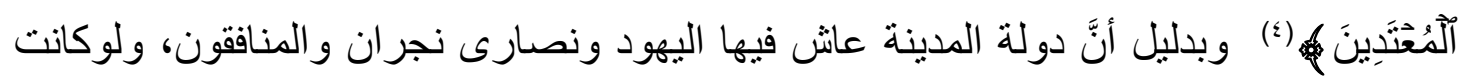

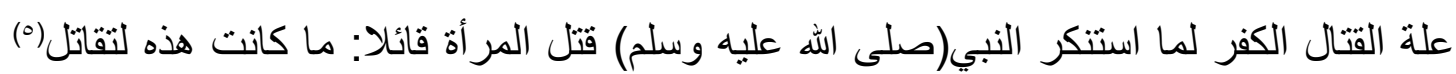

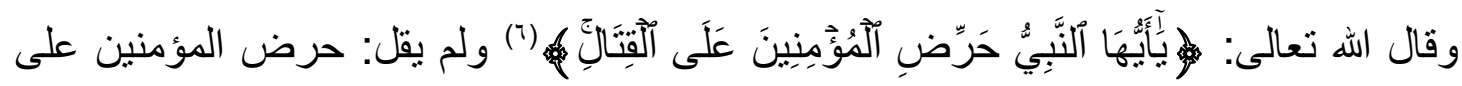

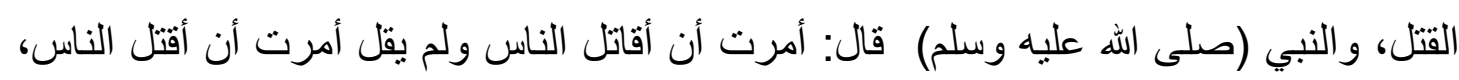

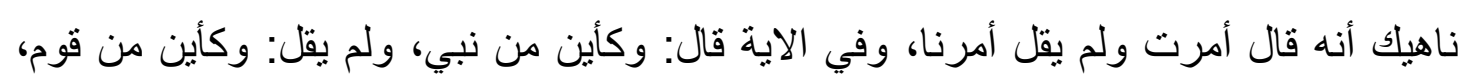

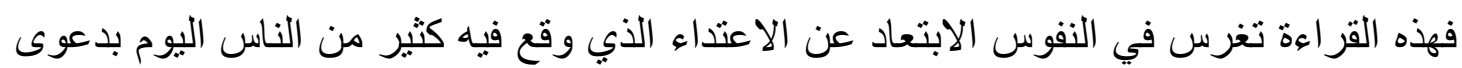

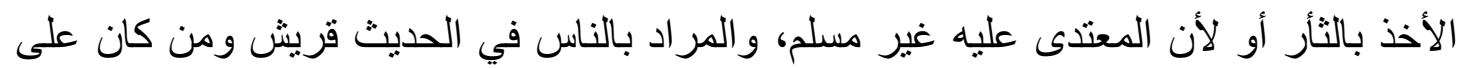
شاكلتهم في الاعتداء و التآمر.

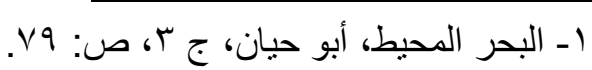

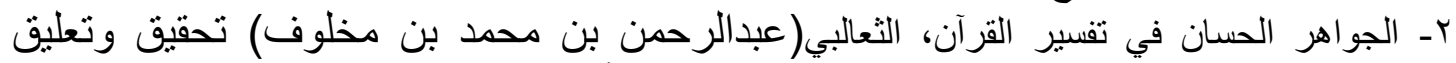

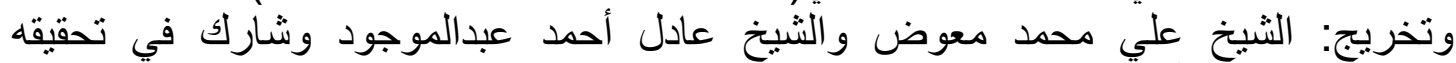

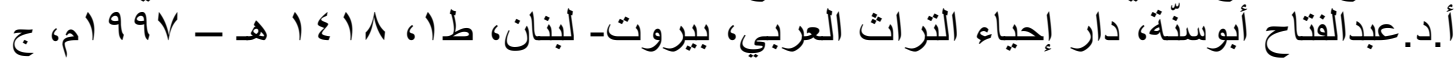

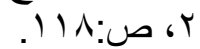
rا الجهاد أعم من القتال، فصور الجهاد كثيرة، منها: بر الو الدين، الحج والعمرة، كلمة الحق عند سلطان جائر،

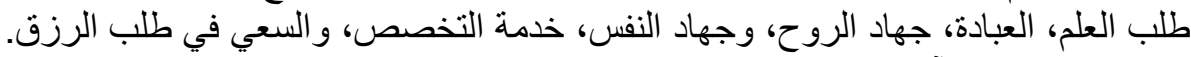

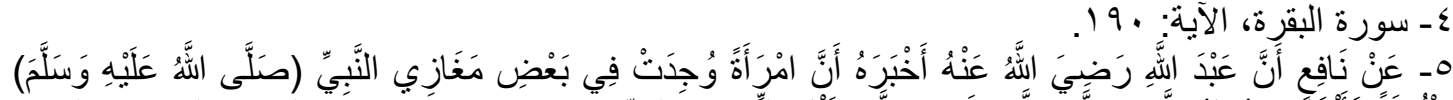

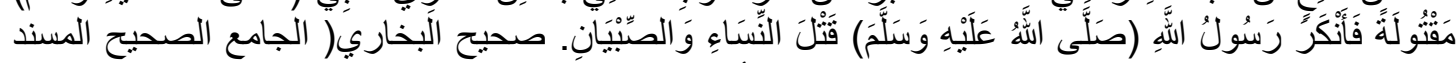

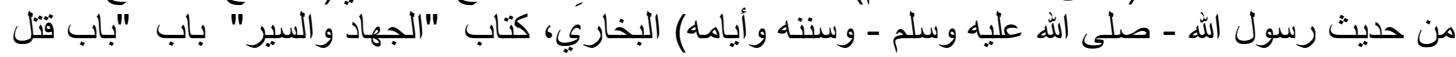

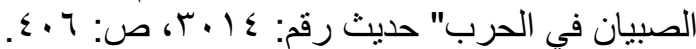

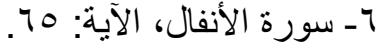


فالجمع بين القراعتين يُظْهِر وسطية الإسلام، ويَرَدّ على مَن يقول بأنَّ الإسلام يأمر بالقتل

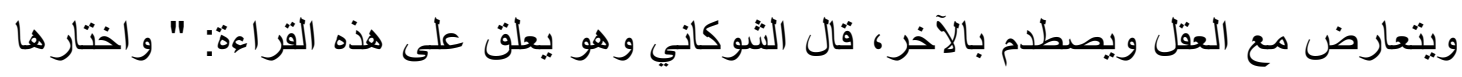

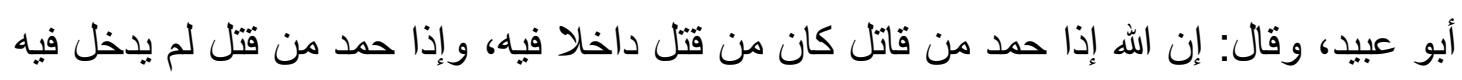

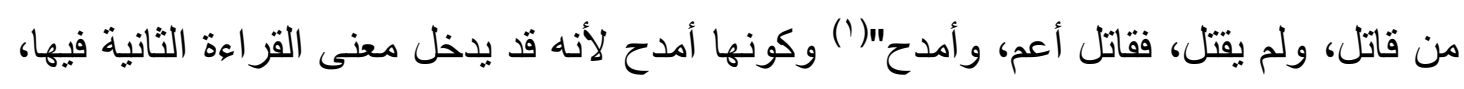
ولأنه لو استطعنا أن ندافع عن أنفسنا ونأخذ حقنا دون إسالة دماء فهو أولى و أفضل.

والآية على القراءتين فيهما: تسلية للمؤمنين ورفع لعزيمتهم، تسلية للمؤمنين في قراءة (قُتل)

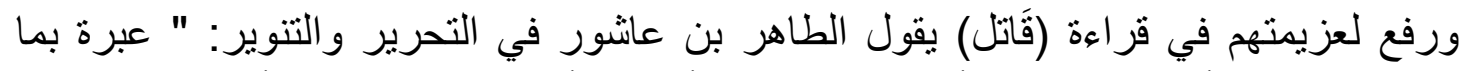

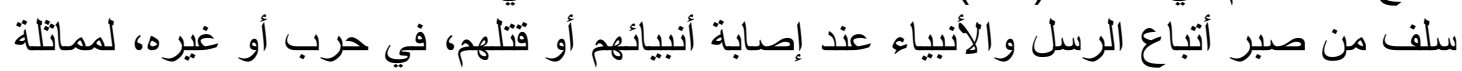

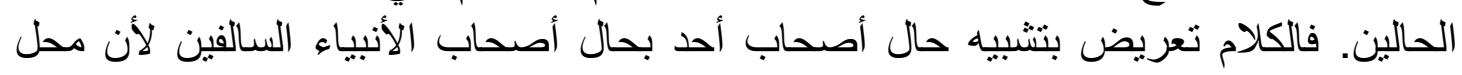

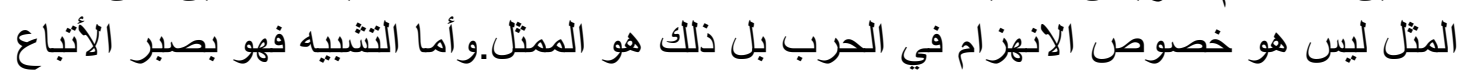

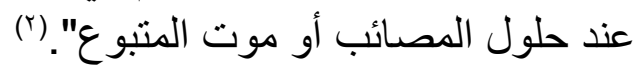

\section{ثالثاً: مظاهر الوسطية وأهميتها}

للوسطية مظاهر ومعالم، ذكر صاحب كتاب (الوسطية الطريق إلى الغذ) بعضا منها وهي: (-

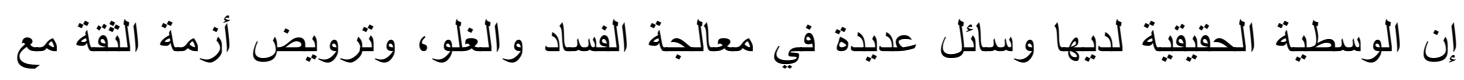

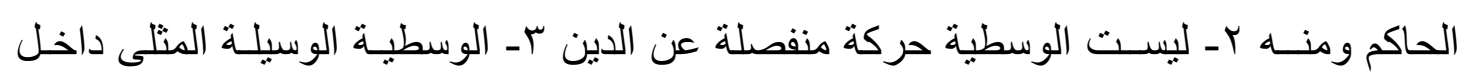

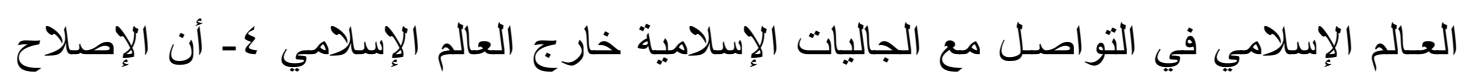

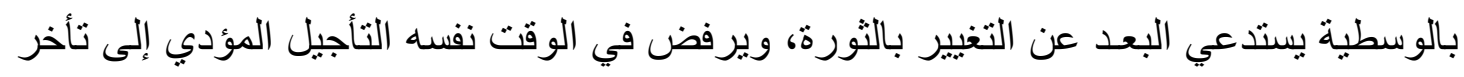

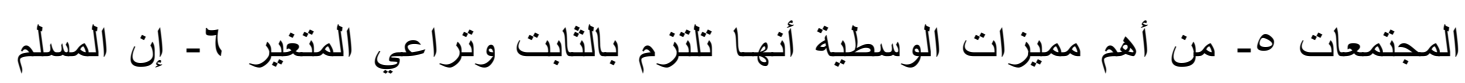

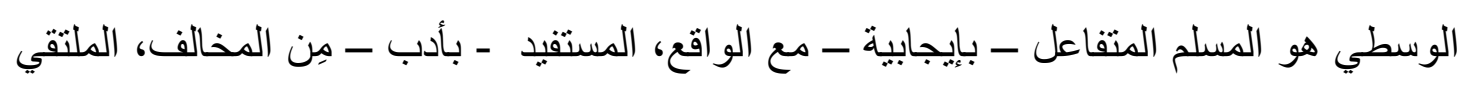

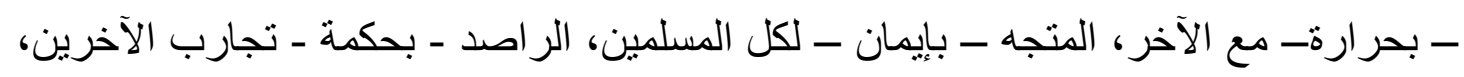

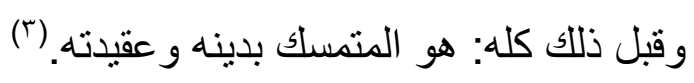

و الملاحظ على هذه المعالم التي ذكر ها أن أغلبها ليست معالم عامة؛ إنما هي معالم خاصة؛ كما

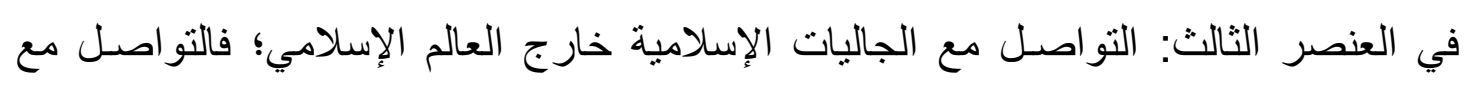
الجاليات صورة أو تطبيق خاص للوسطية وليست صورة عامة.

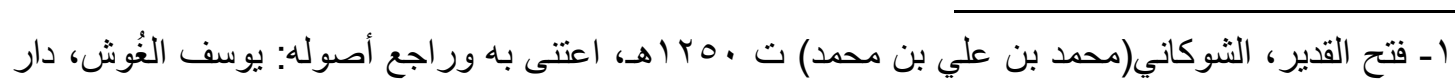

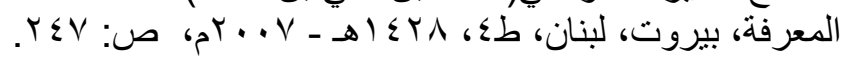

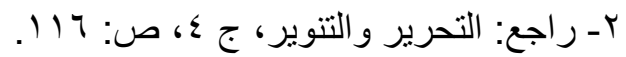

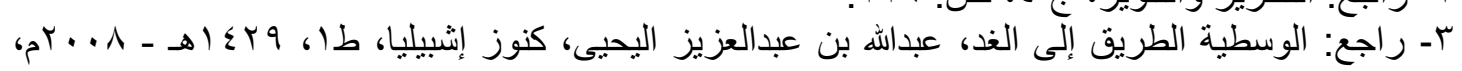

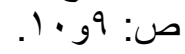


فكل أمر من شـــؤون الحياة قام على الاعتدال، و التوازن، والموافقة للأحكام الثرعية من غير

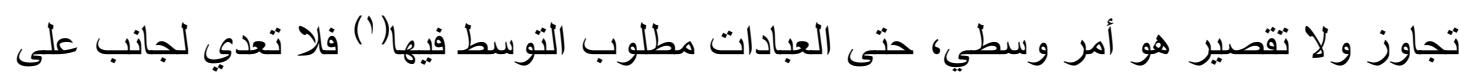

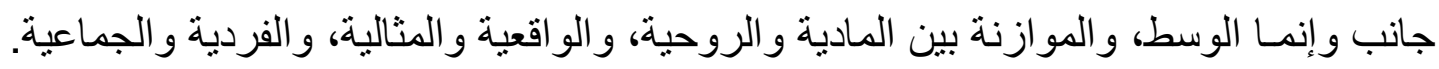
وتحدث صاحب رسالة (الوسطية ومظاهر ها في القرآن الكريم) عن ثلاثة مظاهر للوسطية هي:

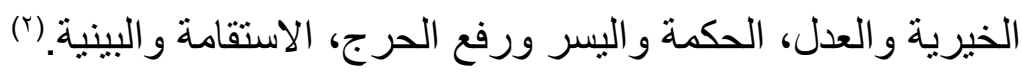
و الإسلام حريص كل الحرص على أن يعيش الناس في أمن وأمان وسعادة وطمأنينة، لذلك

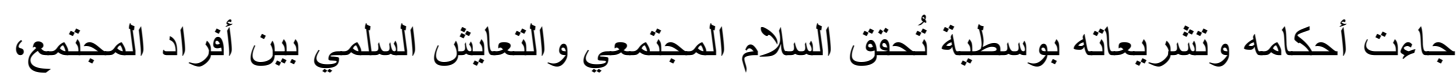

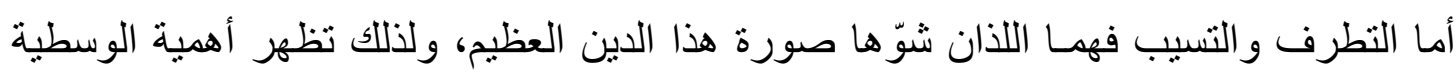

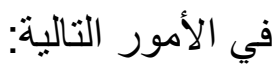

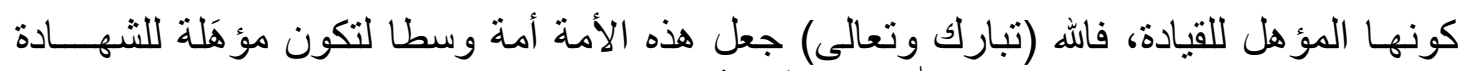

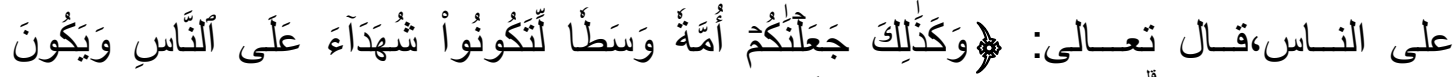

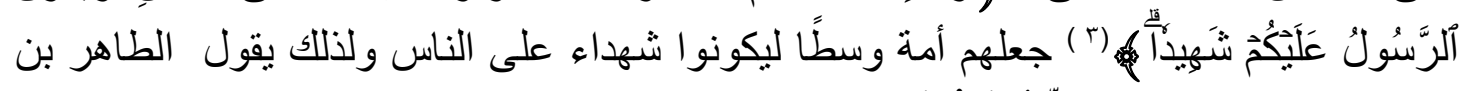

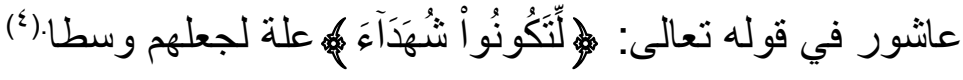

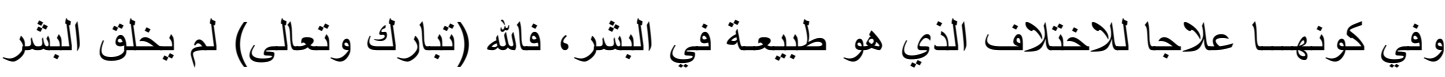

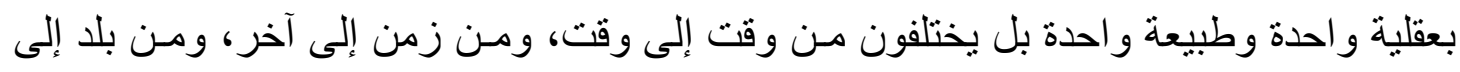
بلد، من حالة إلى أخرى، وحرصا على تحقيق الوسطية كانت وصية النبي (صلى الله عليه

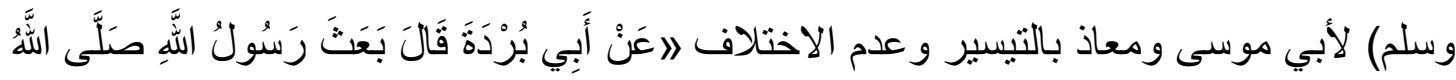

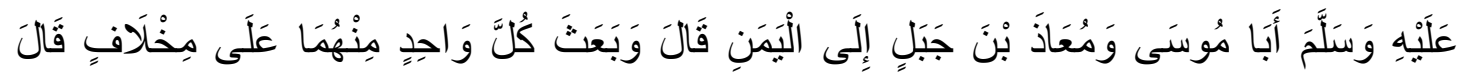

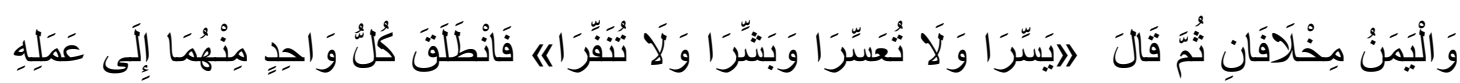

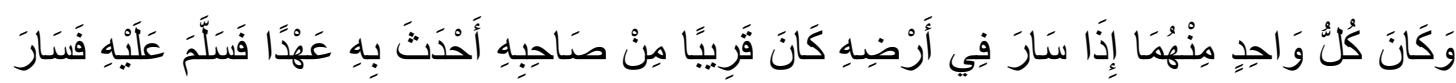

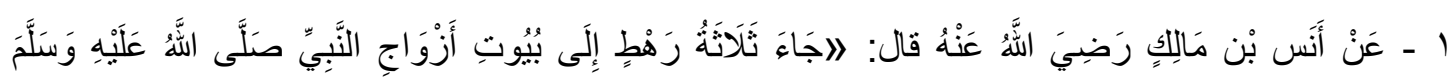

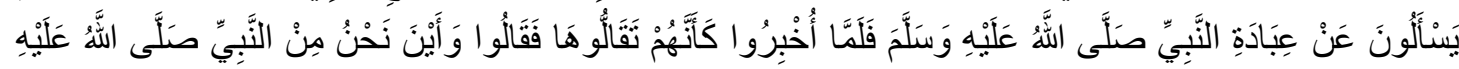

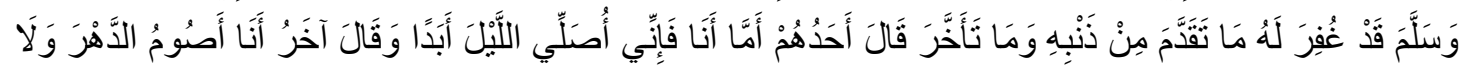

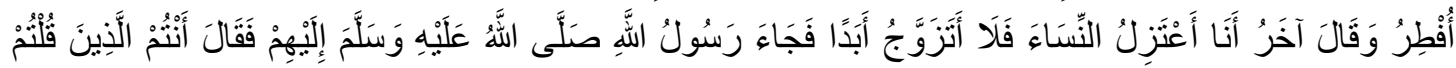

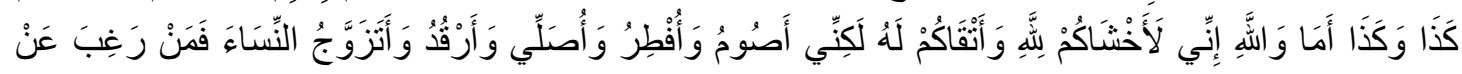

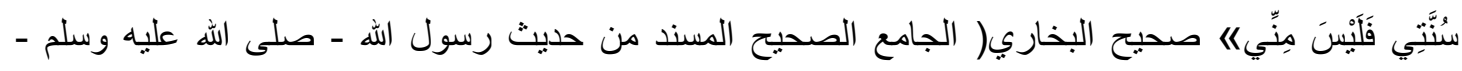

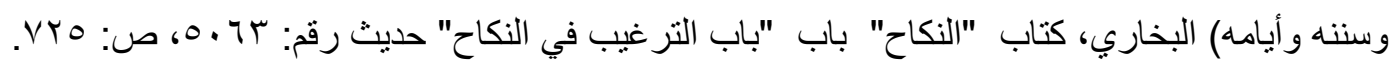

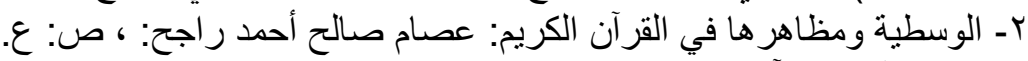

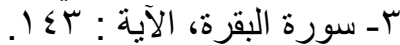

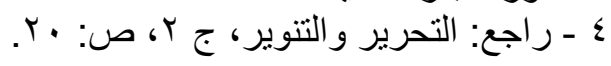




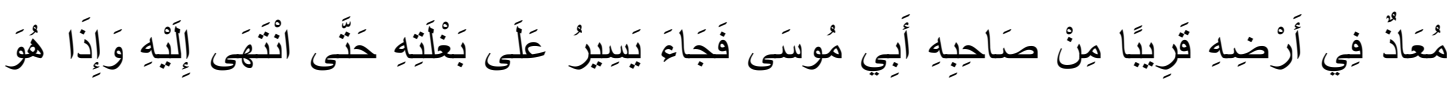

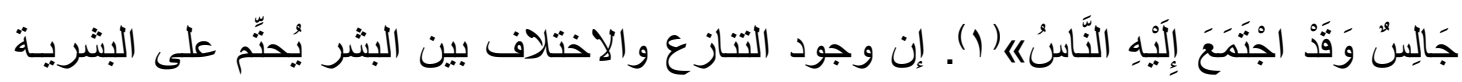
البحث عن العدل و الوسط الذي يقلل من هذا الاختلاف الذي هو دمار للمجتمعات و الأم.

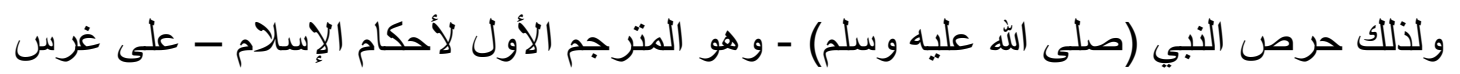

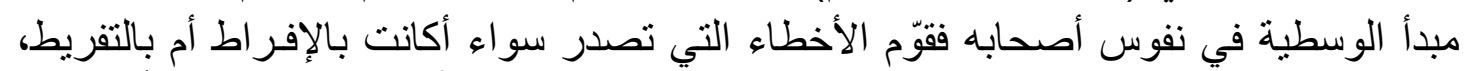

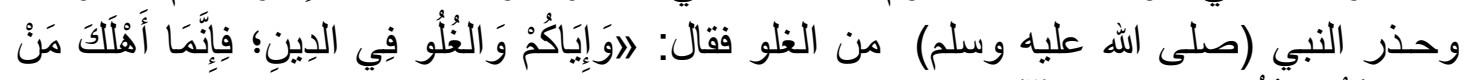

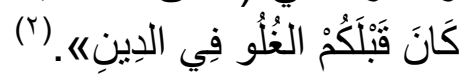

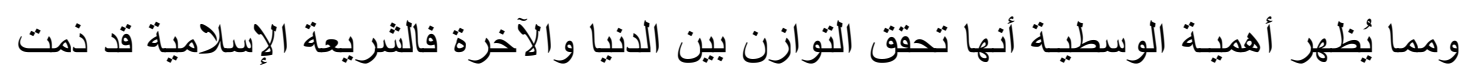

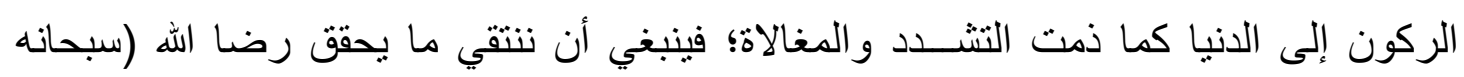

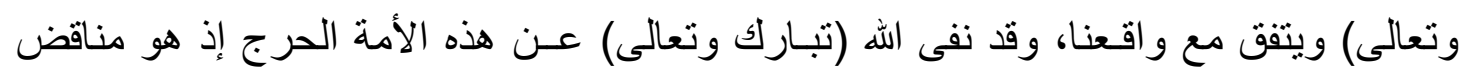

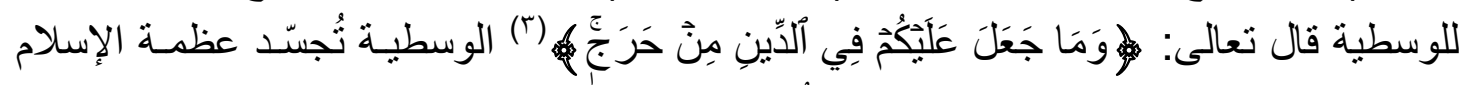

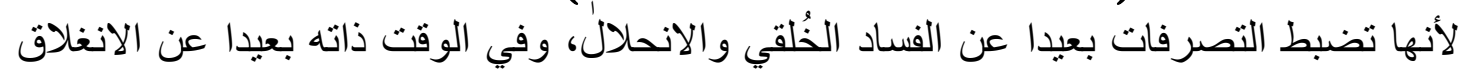
و الكر اهية و التشدد، وهذه هي العظمة: أن نكون بعيدين عن الطرفين السيئين.

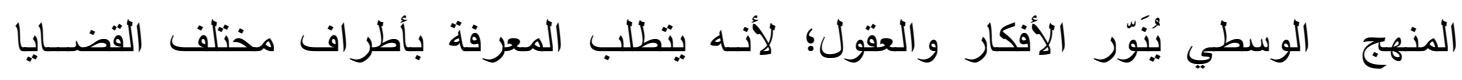

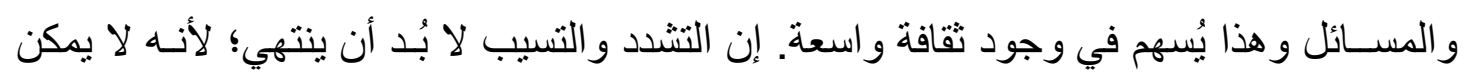

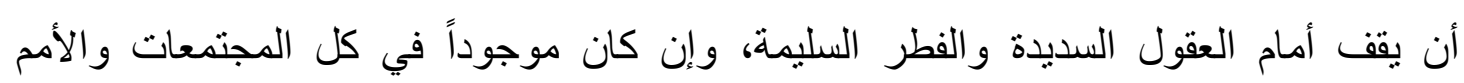

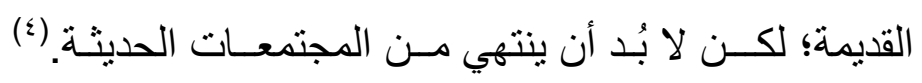

و الإسلام ديـن الوسطيـة فليس فيه استعـلاء و لا خنوع، وليس فيه ذل ولا استكبـار، وليس فيه

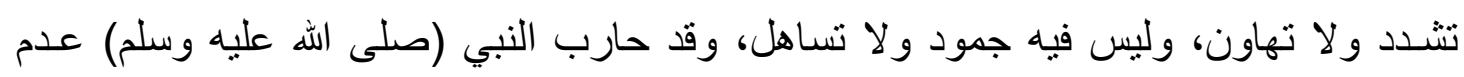

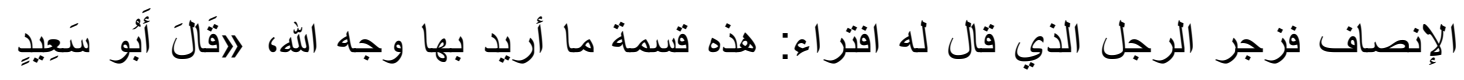

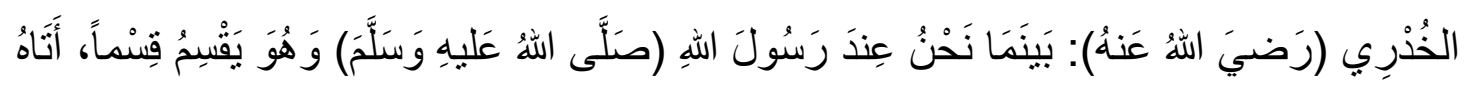

1 - صحيح البخاري (الجامع الصحيح المسند من حديث رسول الله صلى الله عليه وسلم- وسننه و أيامه)

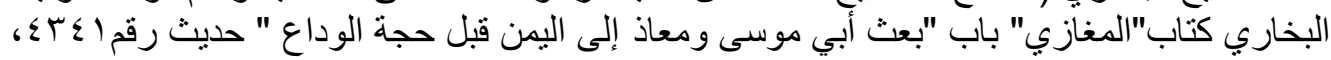

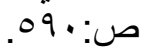

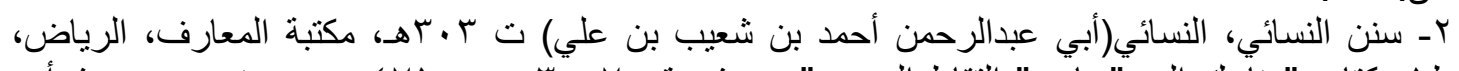

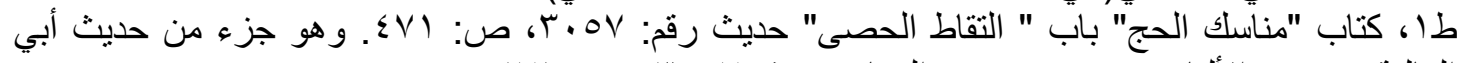

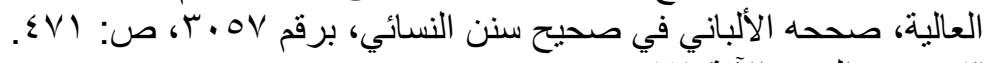

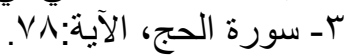

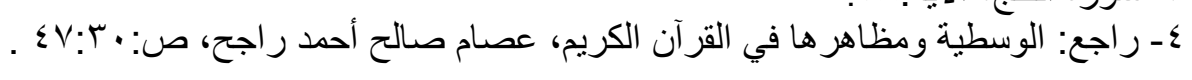




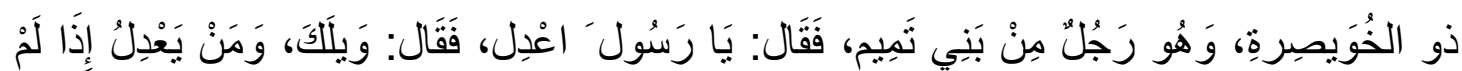

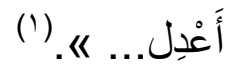

\section{رابعاً: أقسام الوسطية وصورها}

الوسطية موجودة في كل قضــايا الإسـلام، في العقائد، و العبادات، و المعاملات، وفي المبادئ و الأفكار و المذاهب و والمفاهيم، وفي الحياة الروحية و المادية.

وسطية في العقيدة، ففي جانب الغيب وسط بين مَن لا يُؤمنون إلا بالمحسوس و الملموس

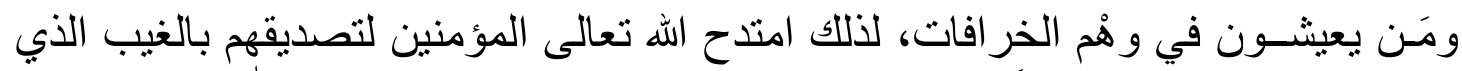

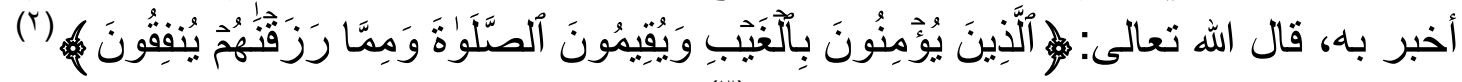

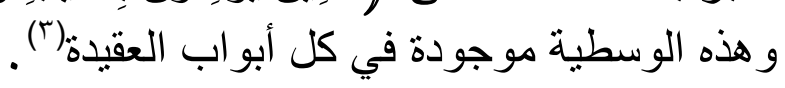

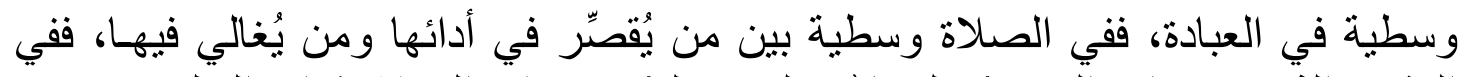

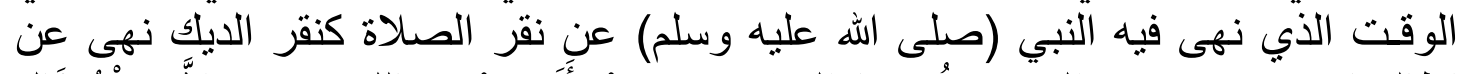

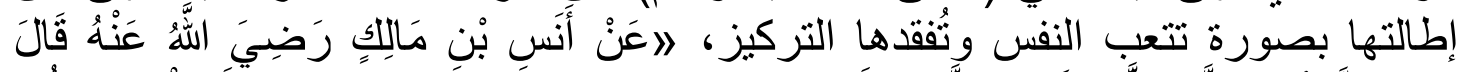

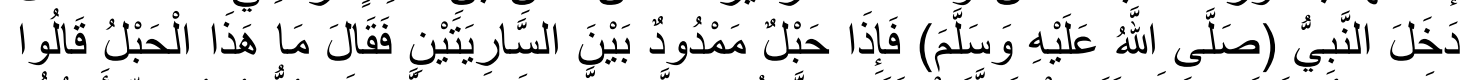

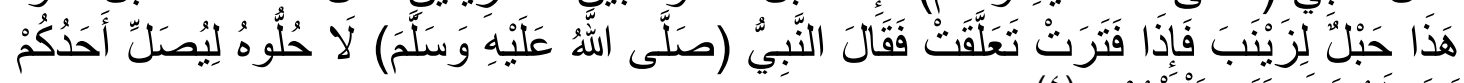

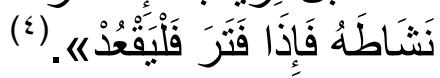

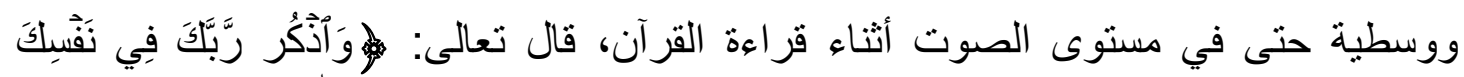

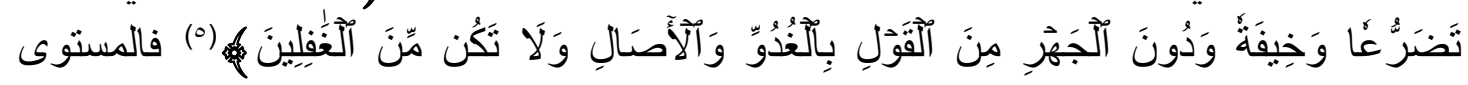

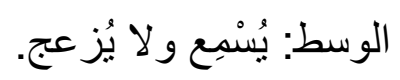

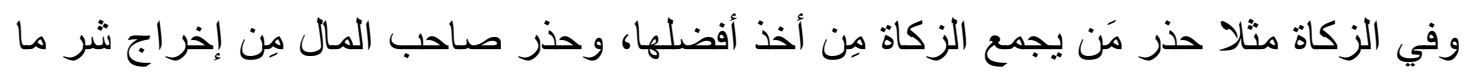

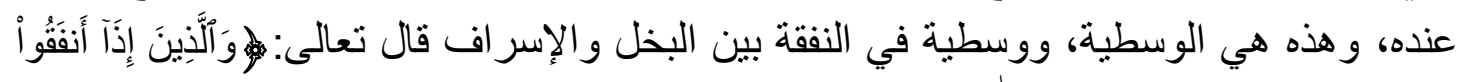

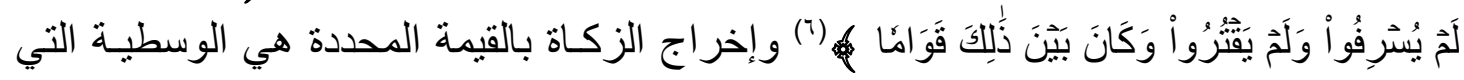

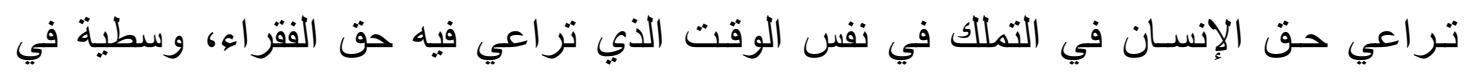

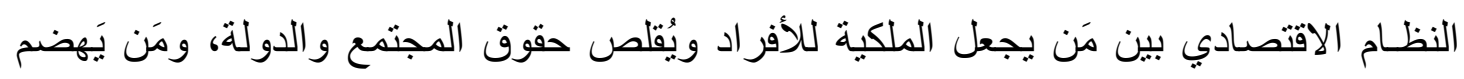

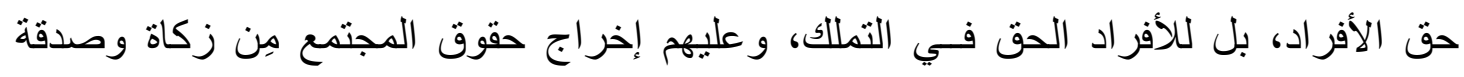

ا- صحيح البخاري( الجامع الصحيح المسند من حديث رسول الها - صلى الهاله عليه وسلم - وسننه وأيامه)

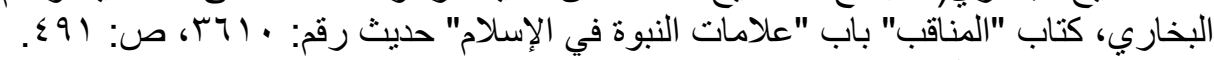

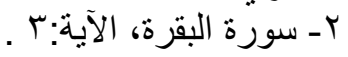

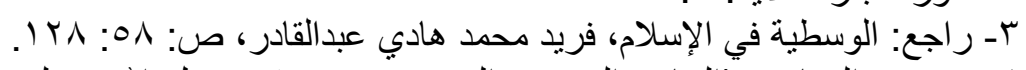

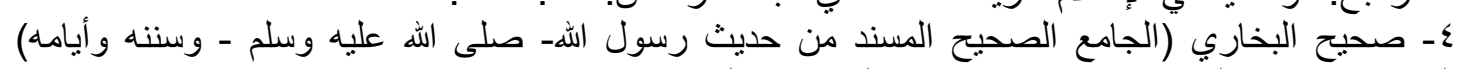

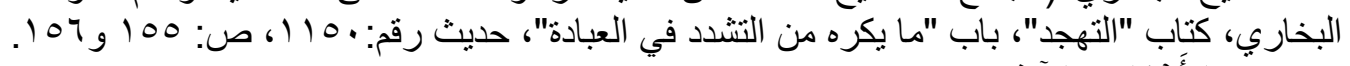

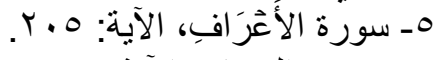

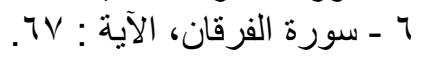


ومساهمـة في البناء والتعمير المساهمة في الأمور العامة دَعا إليها الإسلام، ومِن ذلك دعوة النبي (صلى الله عليه وسلم) لشر اء بئر روماء.

و الوسطية في باب الصوم تقي الإنسان من الهكة والجريمة، فإذا صام العبد كل يوم

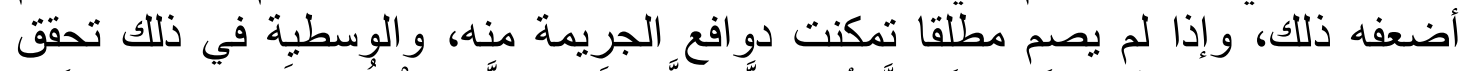

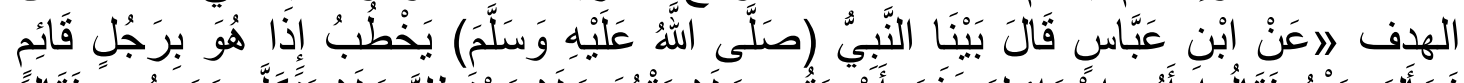

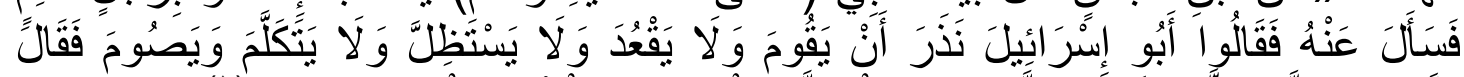

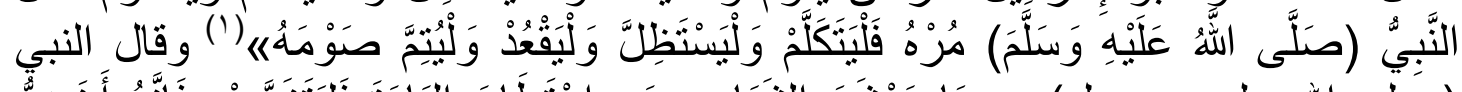

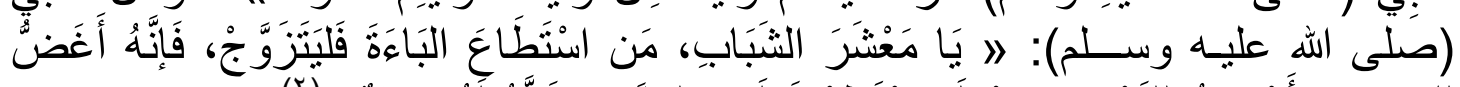

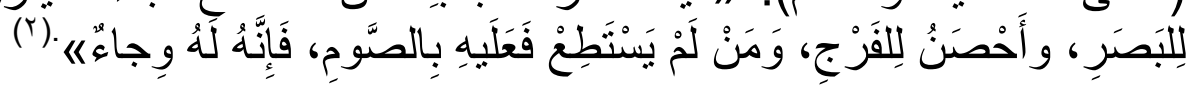

وتظهر الوسطية في العقوبات التي ما شُر عت إلا للتقويم، ففي عقوبة القتل تفرقة منطقية بين

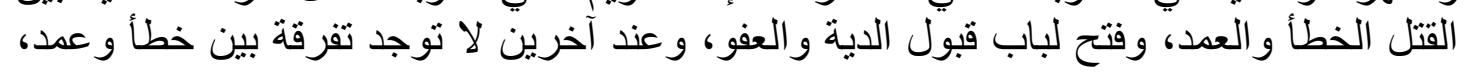

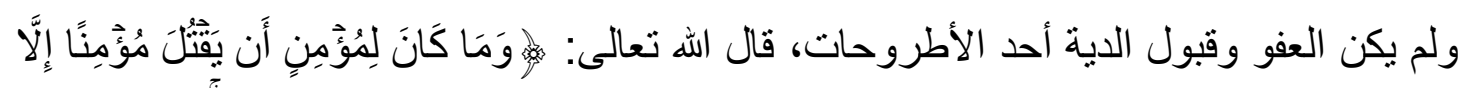

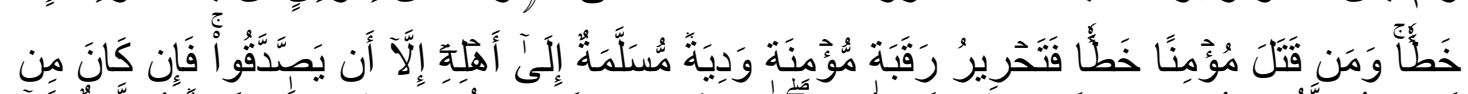

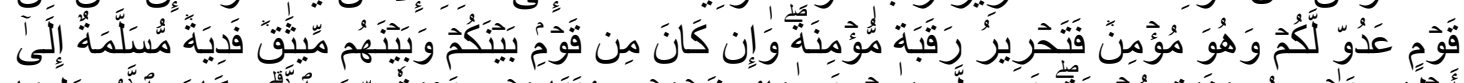

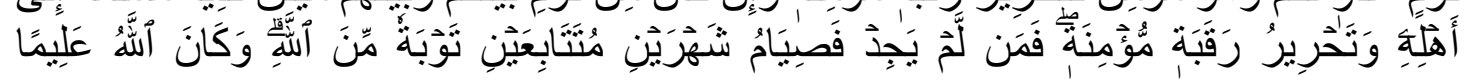

(r) حَكِيمَا (r)

وسطية في المعاملات، وسطيـة الإسلام بين الذين منعو أي فائدة تُعطى زيادة على رأس المال

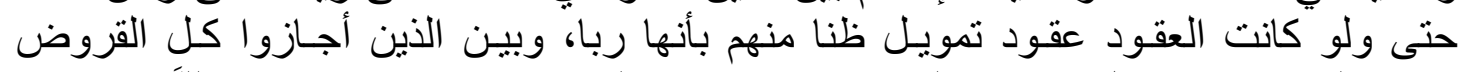

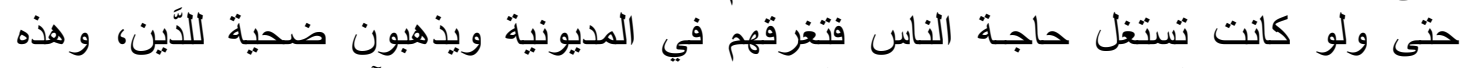

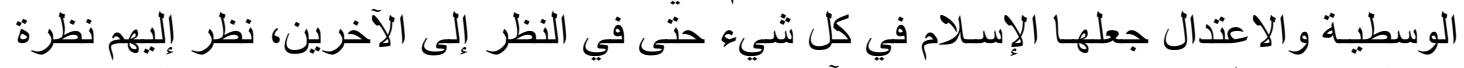

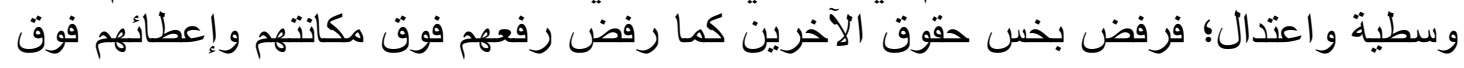

وسطية في المبادئ و الأفكار و المذاهب و المفاهيم، الوسطية في الأحكام القطعية التي شر عها الله ظاهرة

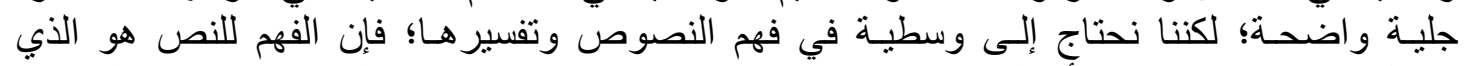

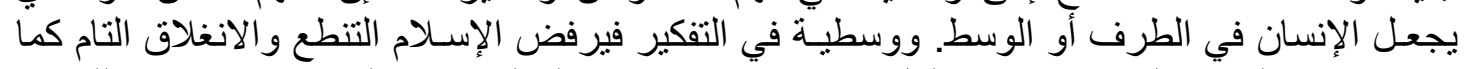

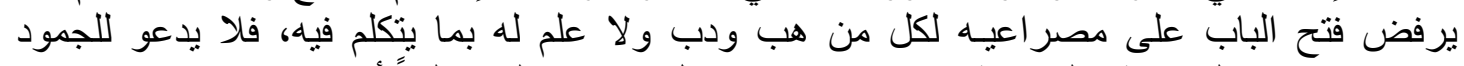

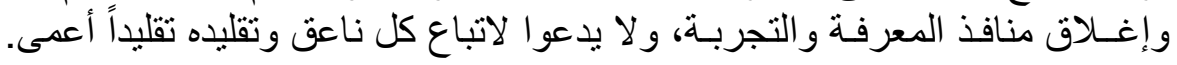

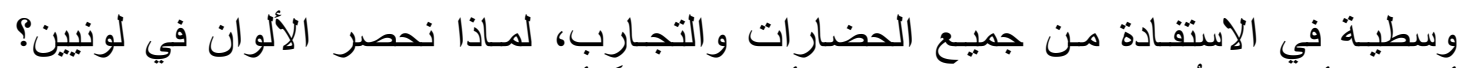

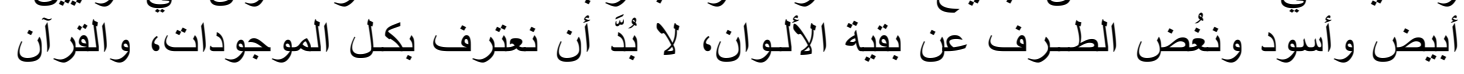

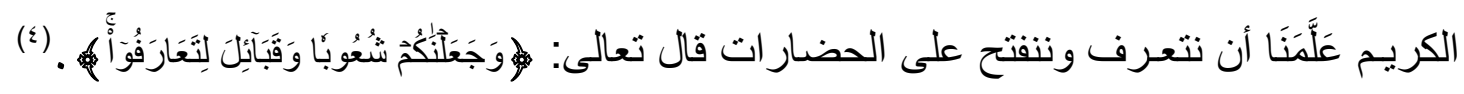

ا- صحيح البخاري (الجامع الصحيح المسند من حديث رسول الله- صلى الله عليه وسلم - وسننه و وأيامه)

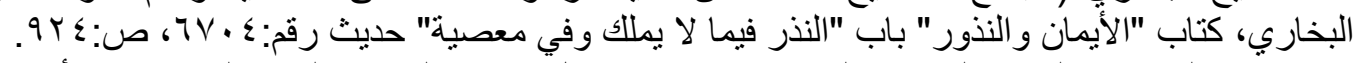

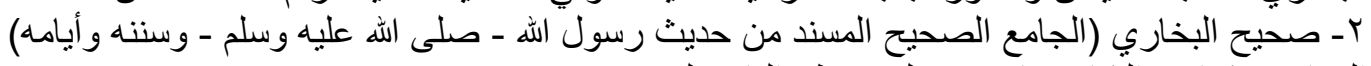

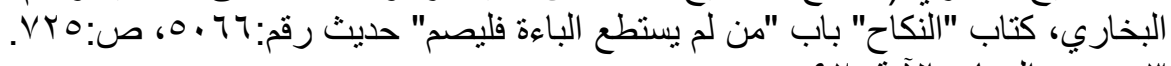
r- سورة النساء، الآية: بو بالب 


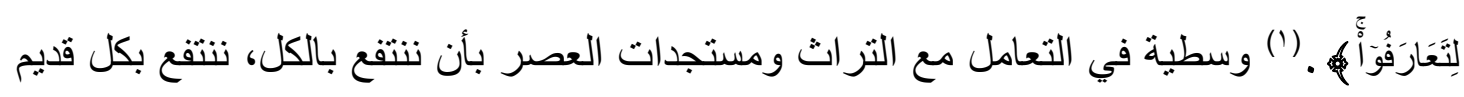

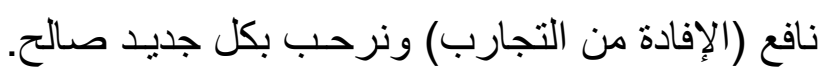

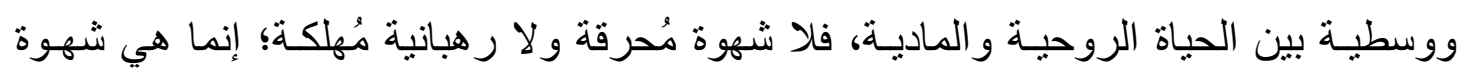

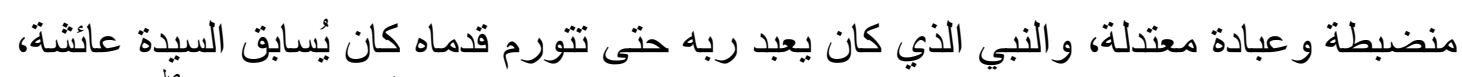

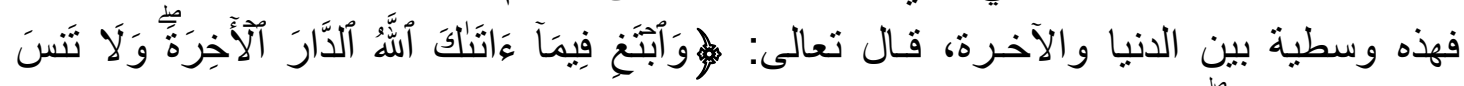

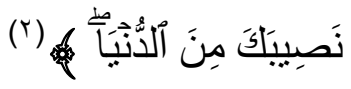

ووسطية في باب الدعوة والتعامل مع الآخرين، فكما أن هذه الوسطيـة في العقائد والعبادات

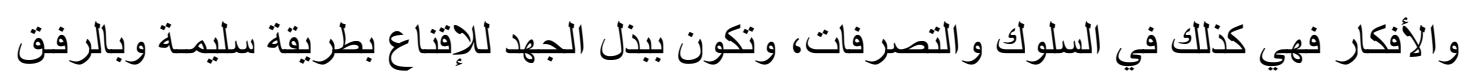

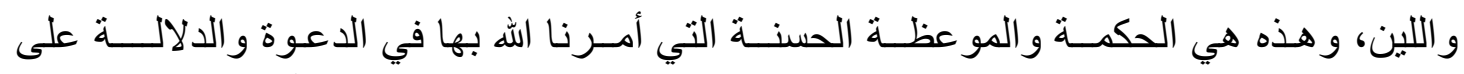

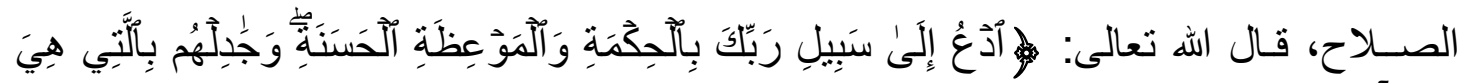

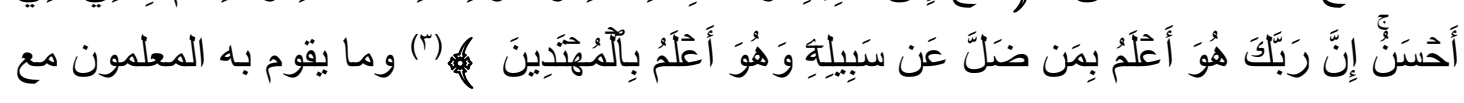

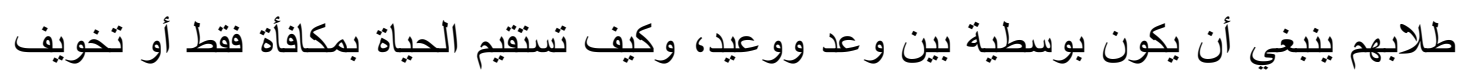

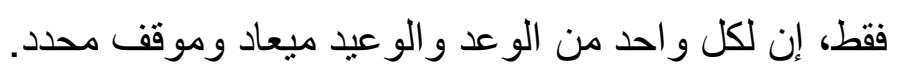
وسطية الإسلام في نظرته ومعاملته للمر أة بين الذين أهانو ها وحرموها حقوقها و الذين عبدوها

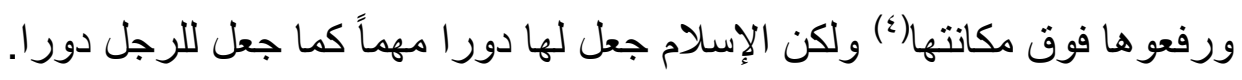

ووسطية في علاقة الفرد بالمجتمع، فلا يعيش الإنسان جشعا لا هم له إلا نفسه، ولا يُلغى دوره

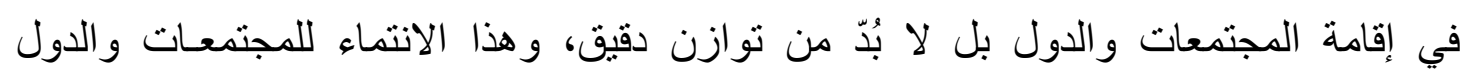

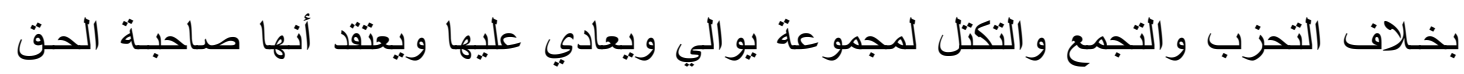
المطلق، وتتمثل الوسطية هنا أيضا في جعل العلاقة بين الرئيس والمرؤس بغير إفراط ولهاب

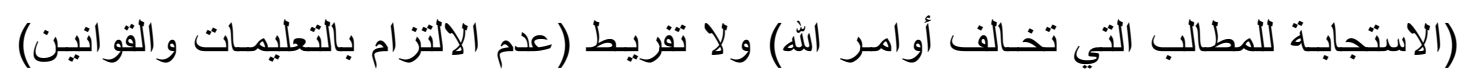

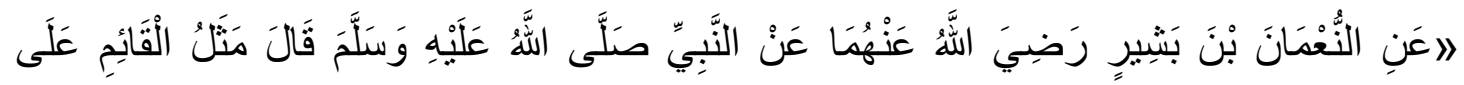

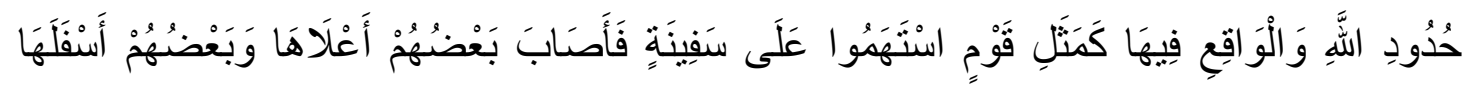

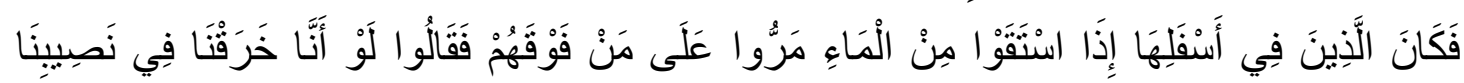

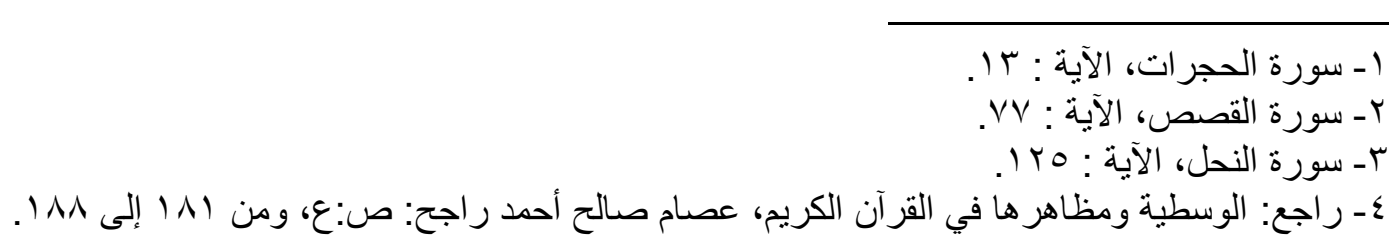




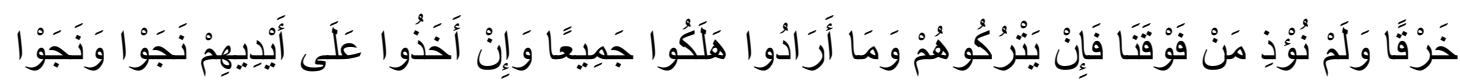

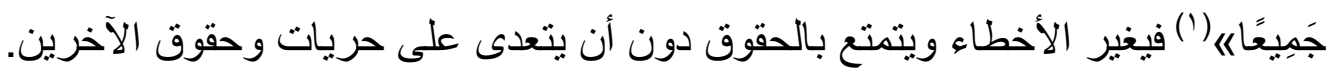

\section{خامساً: وسائل تحقيق الوسطية}

بناء الوعي و المعرفة من أهم ما يحقق الوسطية على أرض الواقع، وتتكون المعرفة من كلام

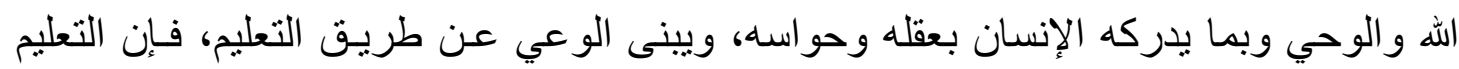

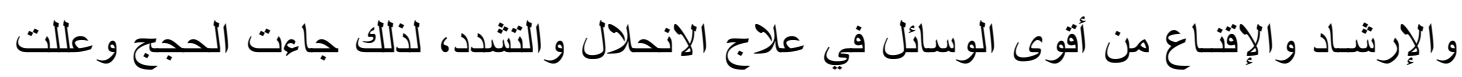

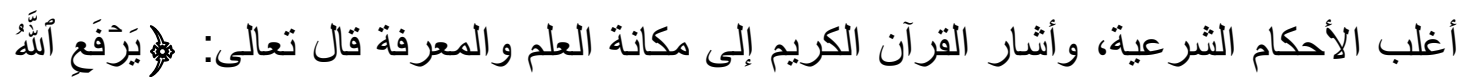

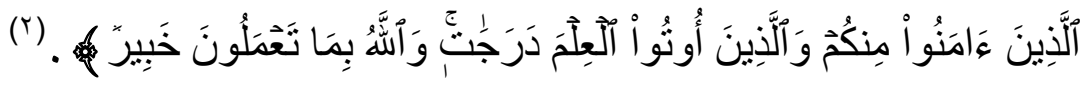

ومـن هذه الوسـائل معرفة الأصول و القواعد ومنها علم الدقاصد؛ فعندما نعرف العلة والحكمة و المقصد من التشريع نستطيع أن نضع الأحكام في مكانها الصحيح دون إفراط أو تفريط، وهذا ونا

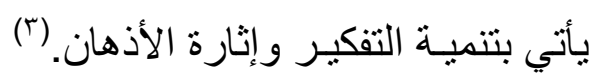

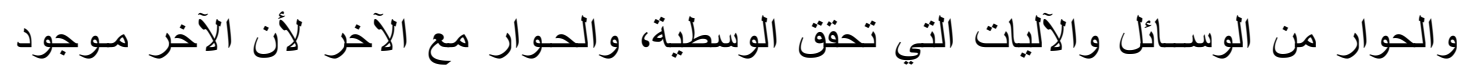

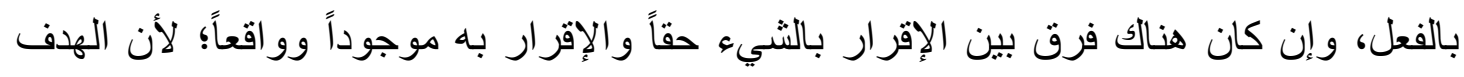

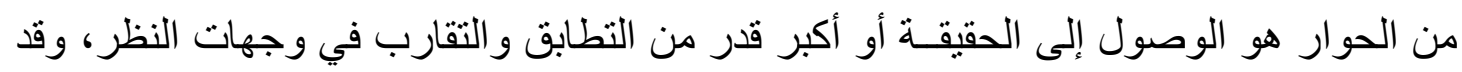

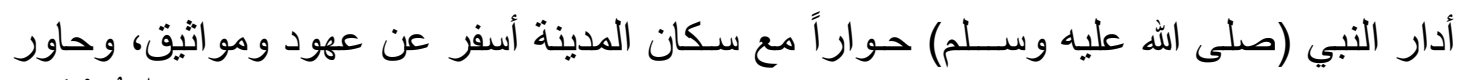

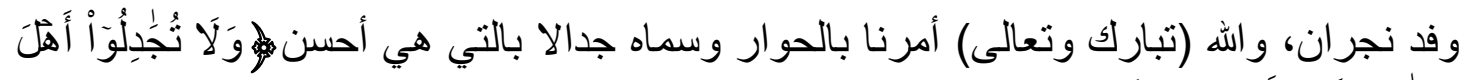

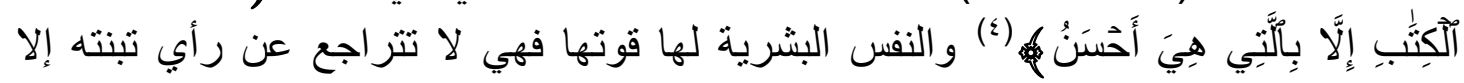
بالحوار برفق حتى لا تشعر بالانهز امية. الإنة

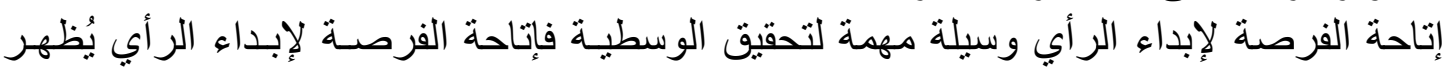

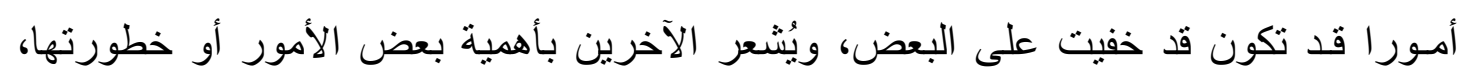

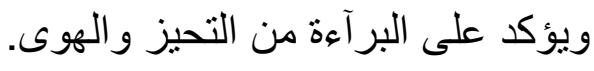

1 - صحيح البخاري (الجامع الصحيح المسند من حديث رسول الهه - صلى الهـ عليه وسلم - وسننه وأيامه)

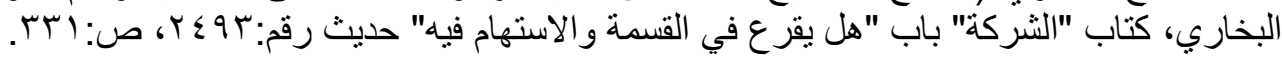

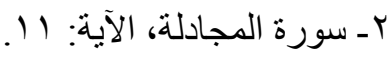

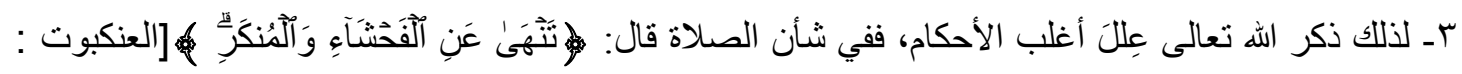

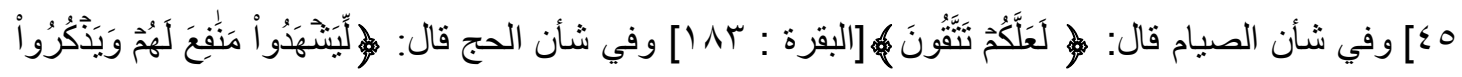

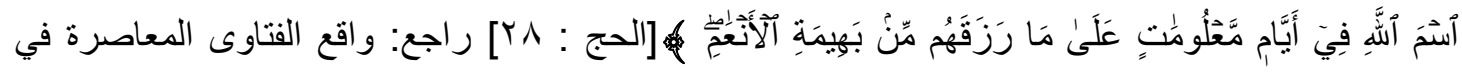

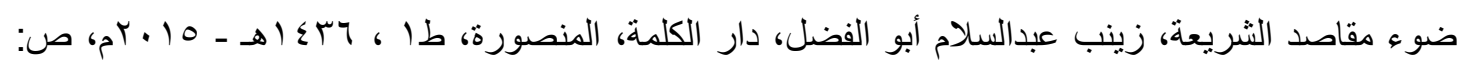


من أقوى الوسـائل في تحقيق الوسطية تحقيق السلامة والصحة النفسيـة وتهيئـة جو بعيد عن

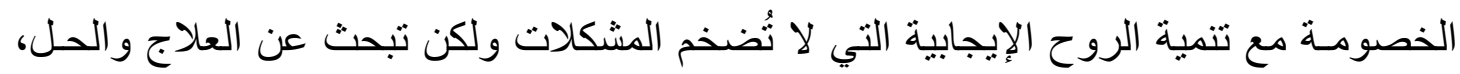
و الر عايـة و الاهتمام بكل الفئات وجميع الأعمار.

وحتى تتحقق الوسطية ينبغي أن نكون قدوة للأجيـال النانثئة وسـطيين في مواقفنا وتصـرفاتنا، ولأن المعلمين قدوة فينبغي أن نغرس الوسطية في نفوس المعلمين وأن نُهيئ المناخ والبيئة الصالحـة لنشر الوسطية، وهذا كله يتطلب منا فهماً عميقاً للنصوص وعدمَ اجتز ائها أو أخذَ بعضا منها دون الآخر.

عمل برامـج تثقفيـة لجميع الفئات و الأعمـار وبخاصة العاملين في المجالات الدينية و التربوية و الثقافية، تهدف هذه البرامـج إلى تنميـة المهارات لدى هذه الفئات لتقوم بدورهـا في مواجهـة

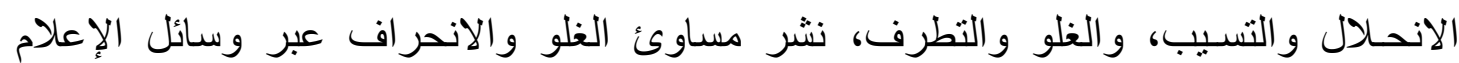
المختلفة بما يُشكل حاجز ا نفسيا عن الغلو والانحر اف لدى لدئ الجميع. حصر الانحر افـات المضـادة للوسطيـة ووضـع خطة لعلاجها تتضمن أسبابَ هذه الانحر افات و الطرق و الوسائل و الآليات و المر احل اللازمة لعلاجها.

\section{سادساً: ثمــار الوســطية}

الوسطية تحقق الأمن والسلام المجتمعي؛ فتجعل الإنسان يَشْعُر ويُشَعِر الآخرين بالأمن

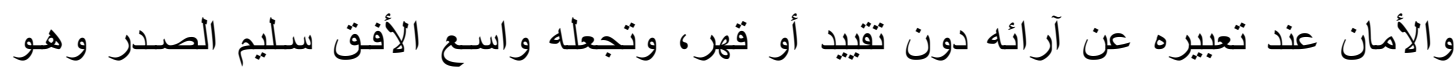

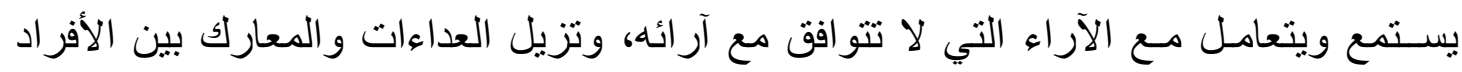

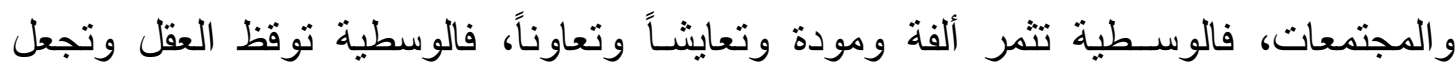

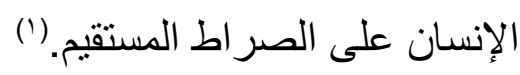

إن الوســية والاعتدال عـلاج للاستبداد والإقصـاء، فـلا شك أن الذي ييحث عن النقاط

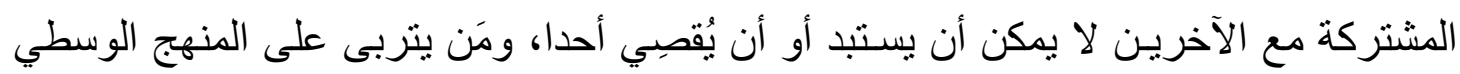

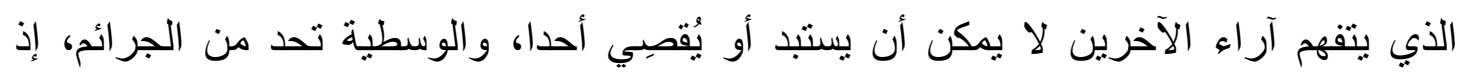
الإفر اط يؤدي إلى جر ائم الإرهاب، و التفريط يؤدي إلى جر ائم انفلات الأن الأخلاق.

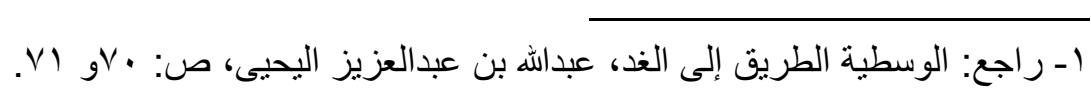


الوسطية تحقق الأمن الفكري الوقائي والعلاجي، تحقق الأمن الفكري الوقائي بترسيخ

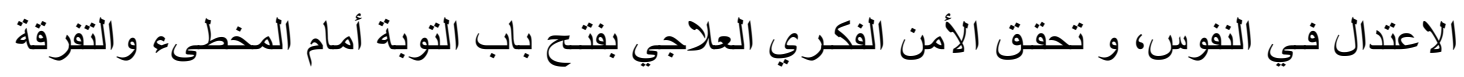
بين من تعدد الخطأ ومن لم يتعدده.

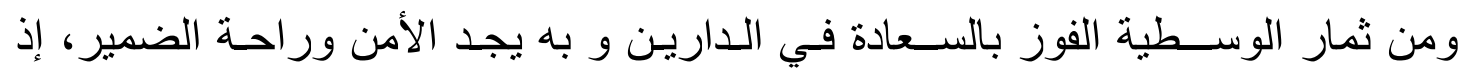

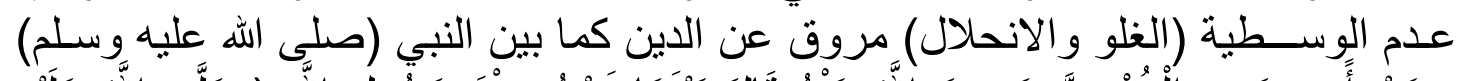

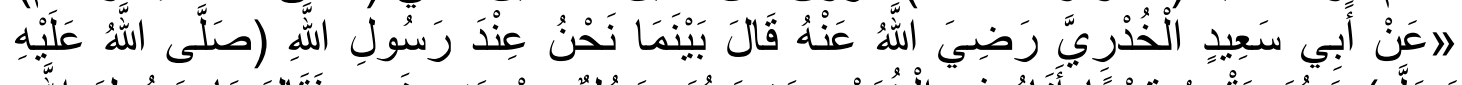

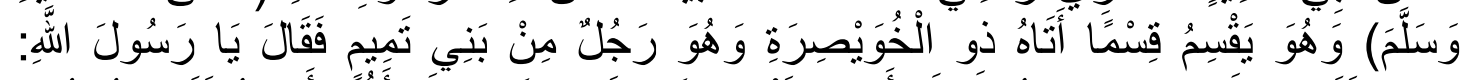

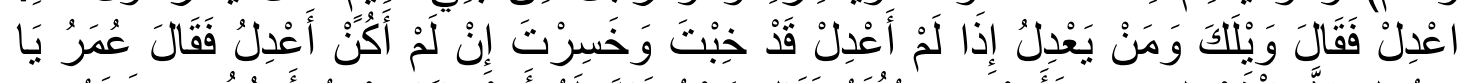

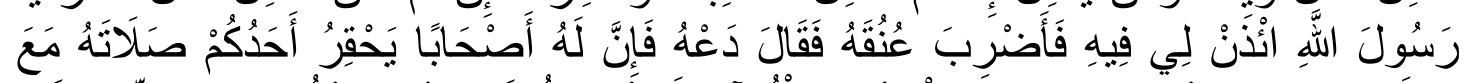

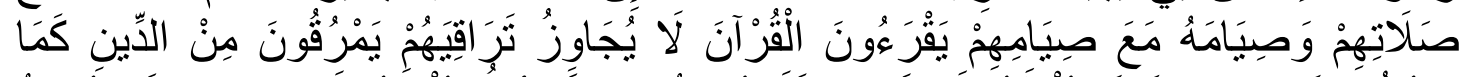

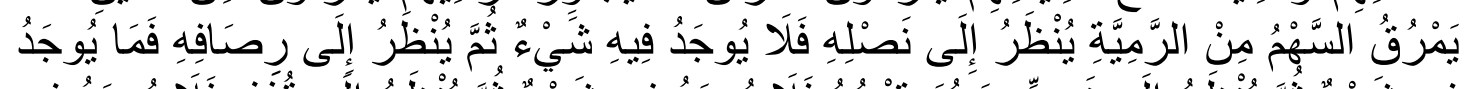

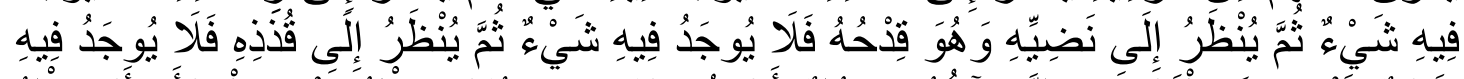

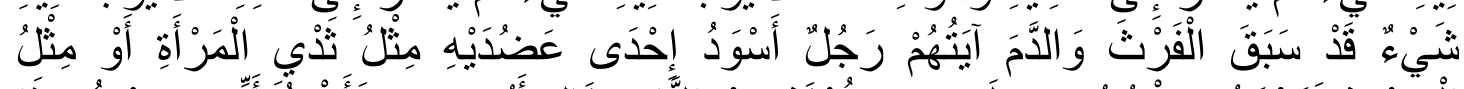

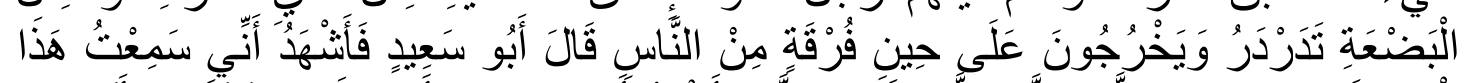

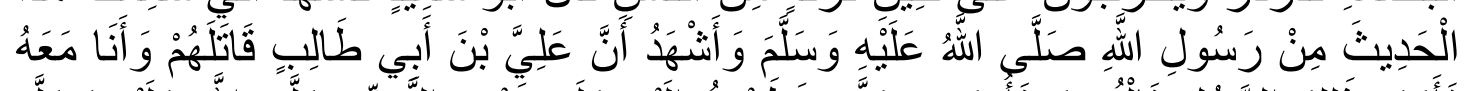

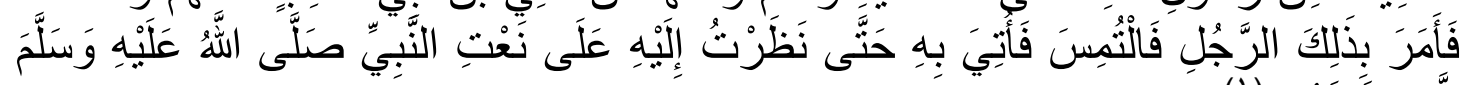

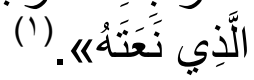

المنهج الوسـطي يقليل الفجوة الموجـودة بين البشـر ويزيـل العداءات، وإن الوسطية التئي

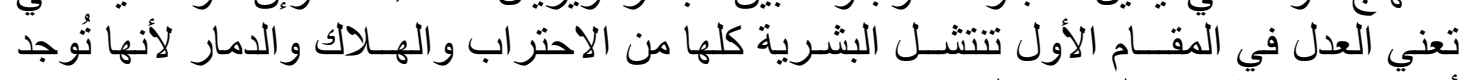
أرضنا مشتركة يقف الجميع عليها.

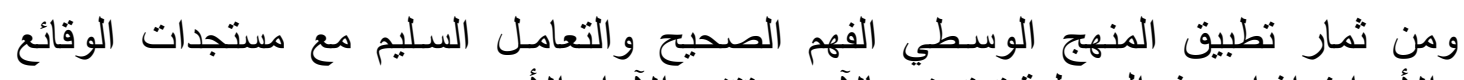
والأحداث إذ إن هذه الوسطية تعترف بالآخر وتتفهم الآراء الأخرى.

\section{سابعاً: معوقات تطبيق المنهج الوسطي ونمي}

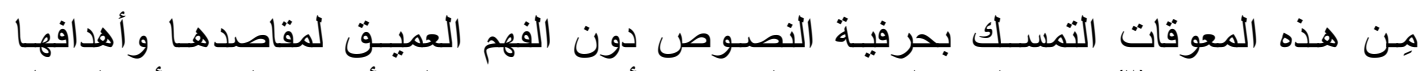

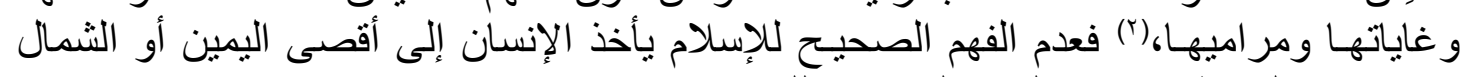

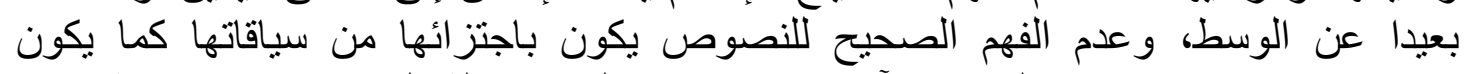

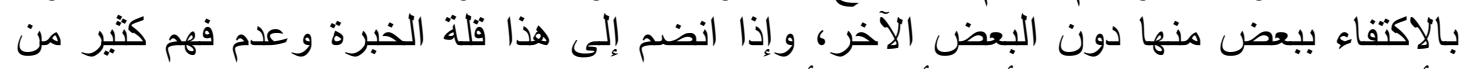

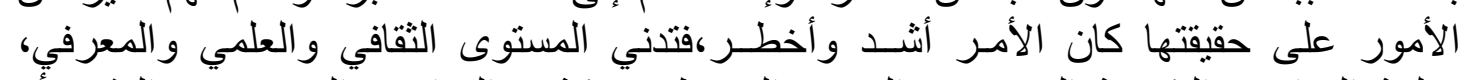

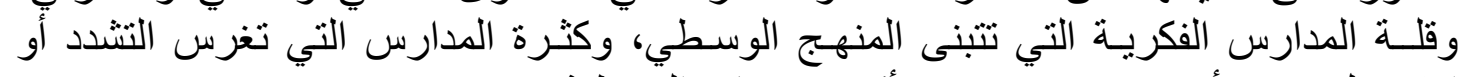
الانحلال بقصد أو بغير قصد هو من أكبر معوقات الونهي الوسطية.

(- صحيح البخاري (الجامع الصحيح المسند من حديث رسول الله - صلى الله عليه وسلم - وسننه و أيامه)

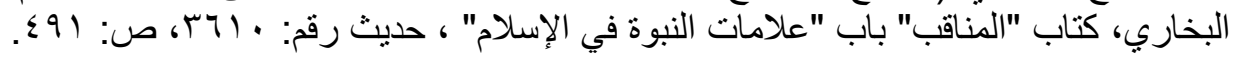

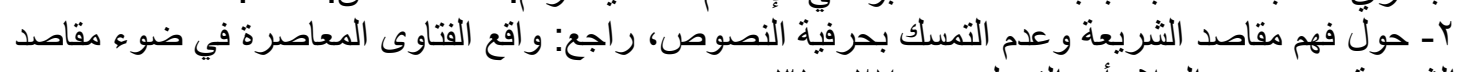

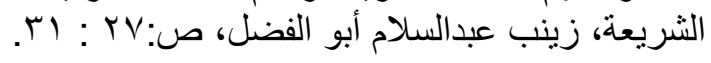




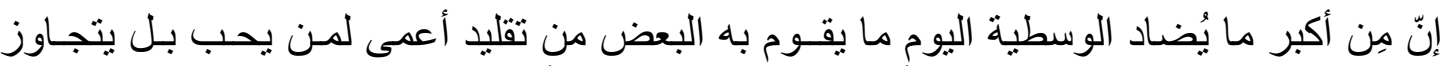

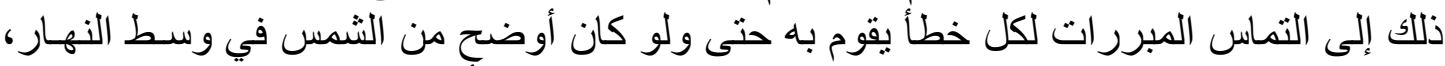

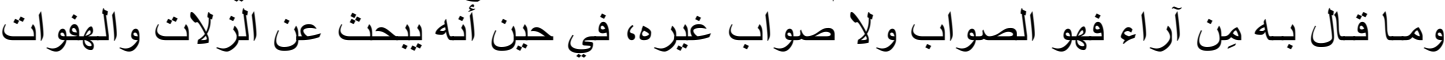

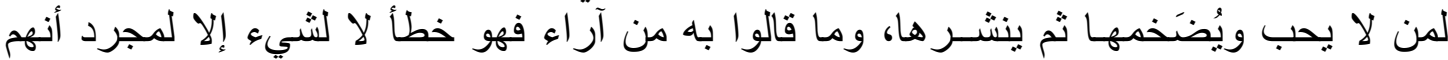
قالو ا به. - مان.

ومن هذه المعوقات الظروف المعيشيـة الصعبـة التي قد تضطر البعض إلى الانخراط مـع

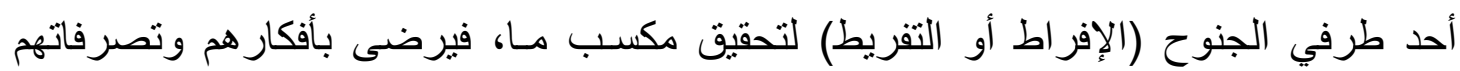

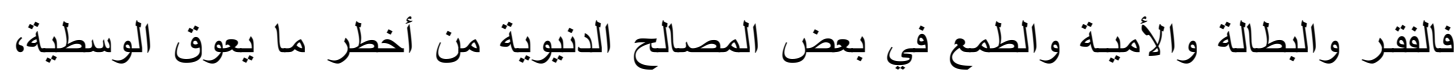

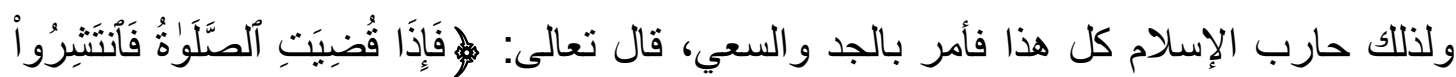

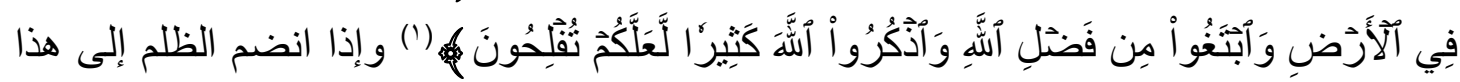

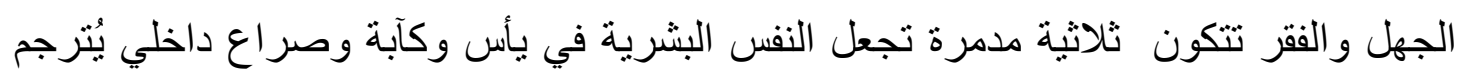
إلى انتقام قد يكون على صورة تطرف وتثدد وقد يكون على صورة تسيب و انحلال. ومن هذه المعوقات عدم وجود عدالة اجتماعية وتكافؤ في الفرص فإن هذا يخلق حالـة من

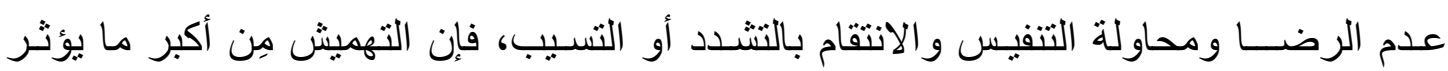

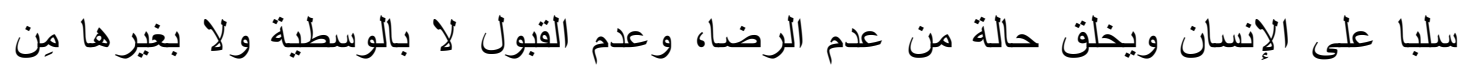

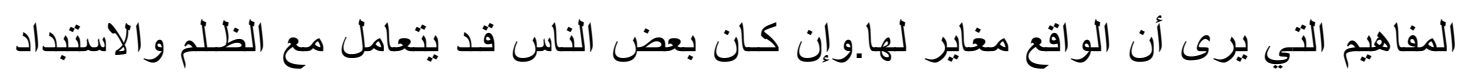

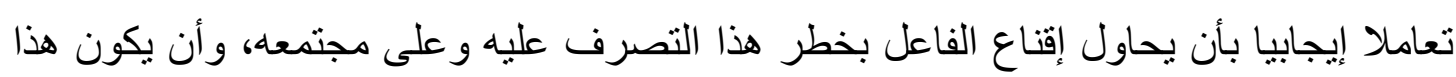

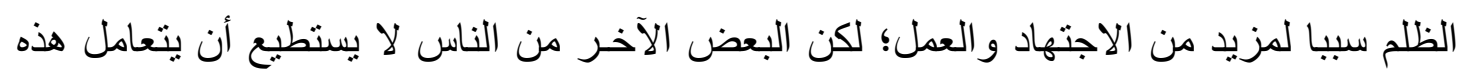

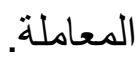

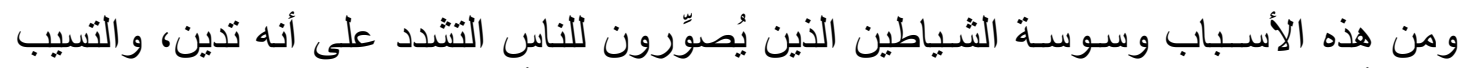

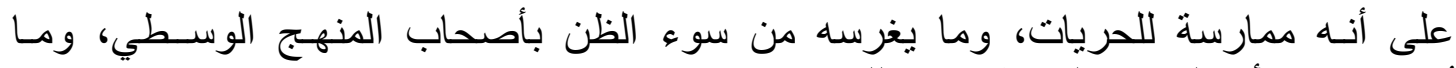

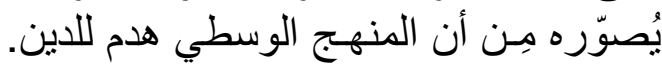

ومن هذه الأسباب تتمية روح الخلاف و افتعال معارك بين الدذاهب، فهذا مما بزيد حدة الأمر ويسهم في بُعد الناس عن الوسطية.

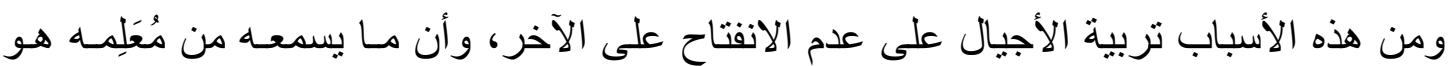

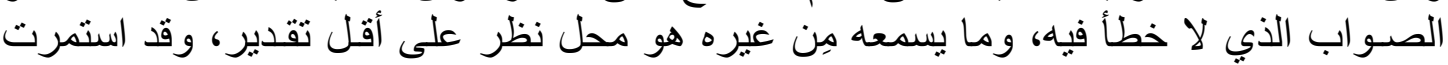
هذه التنشئة الخاطئة لفتر ات طويلة. 


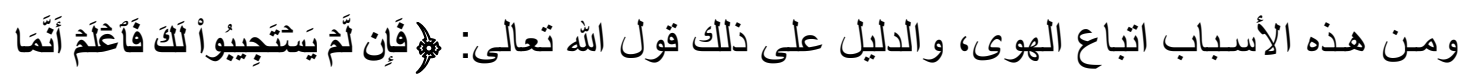

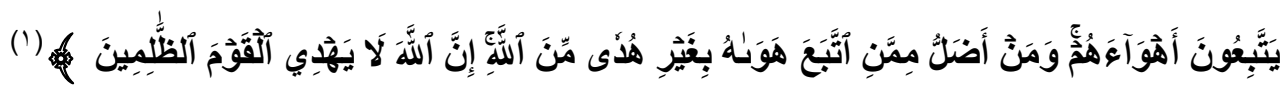

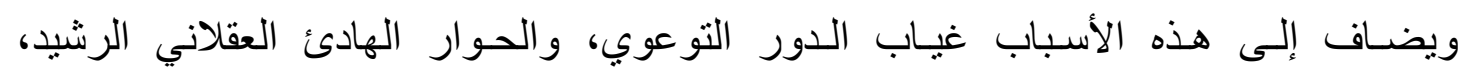

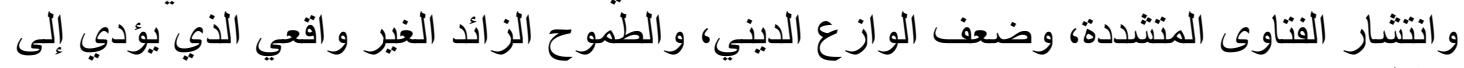
ثامناً: الآثار السيئة للبعد عن المنهج الوسطي مطالب غير عقلانية. من الآثار السيئة للبعد عن المنهج الوسطي: انهيار المجتمع وقد سقطت مجتمعات وأمم بسبب المجون و الانحلال كما سقطت مجتمعات و أمم بسبب الغلو و التطرف و التثدد، وما أجمل

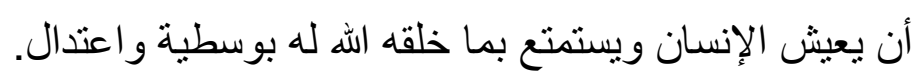
و إذا كان من أظهر معاني الوسطية العدل فإن غيابه سبب لانهيار المجتمع فإذا اختل ميزان العدل وشاع الظلم بين الناس وظهرت المحاباة في التطبيق فإن ذلك سيؤدي إلى بلى بلى

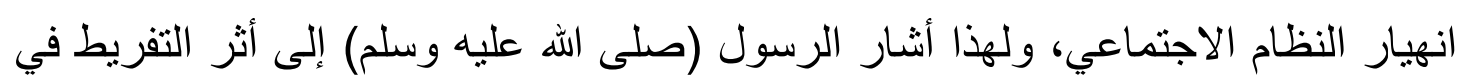

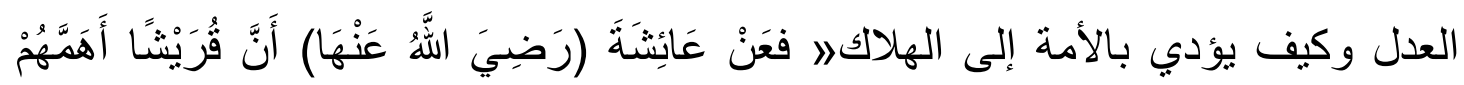

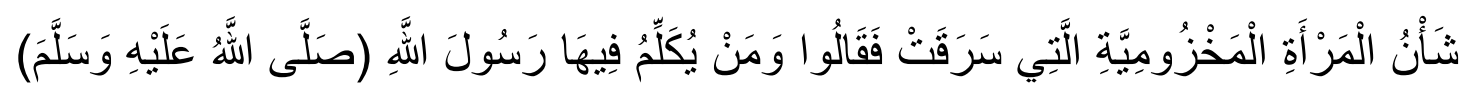

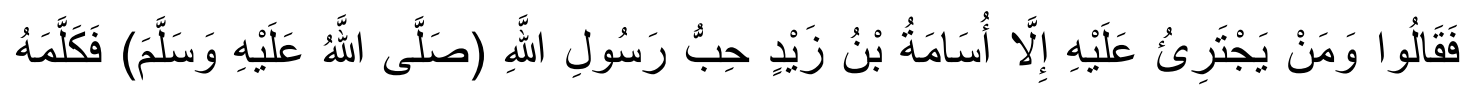

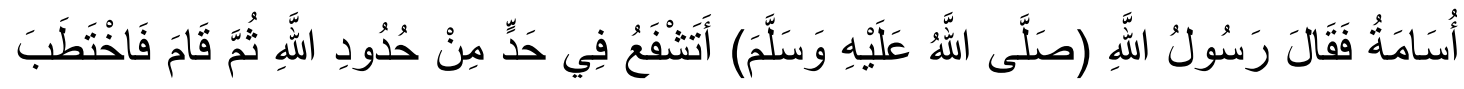

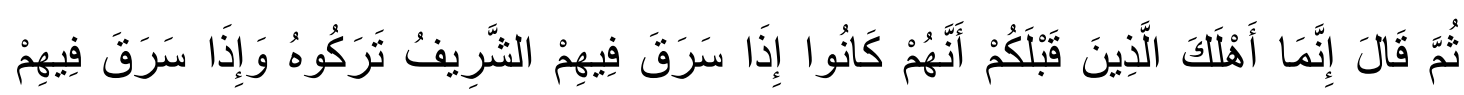

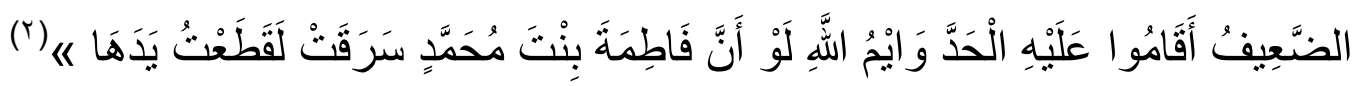

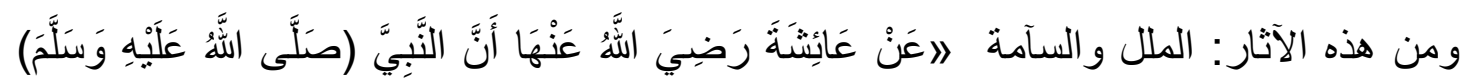

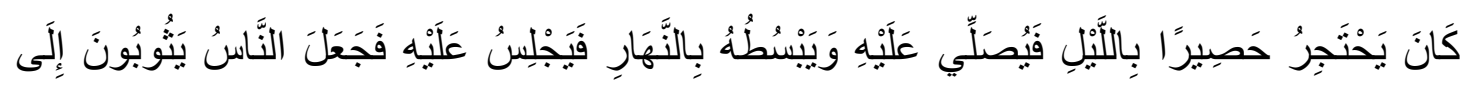

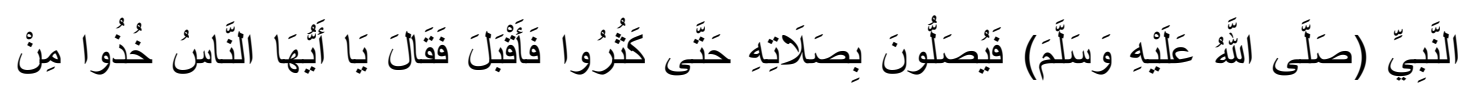

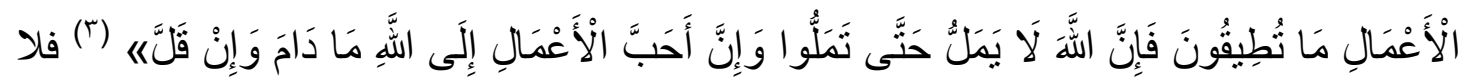

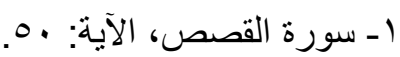

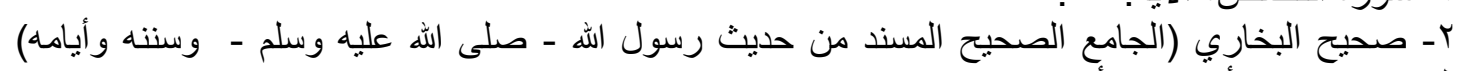

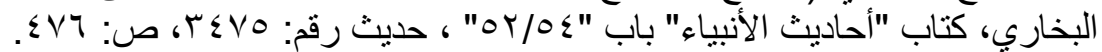

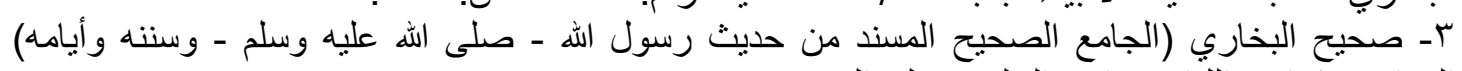

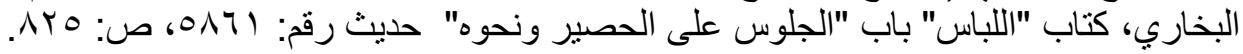


شك أن التعددية التي هي مِن لوازم الوسطية نؤثر تأثير ا إيجابيا على الصحة النفسية للإنسان

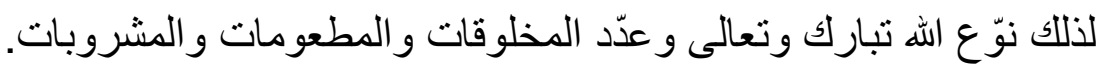

البُعْد عن الوسطية والاعتدال إعراض عن هديه وسنته / عن أَنَسَ بْنَ مَالِلٍِِ رَضِيَ الَّهُ

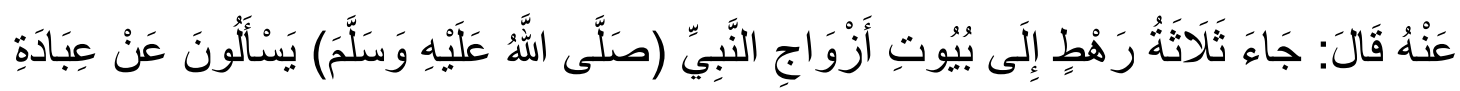

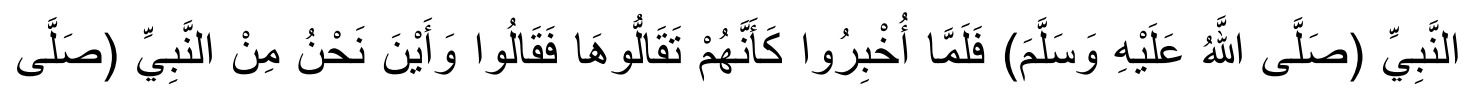

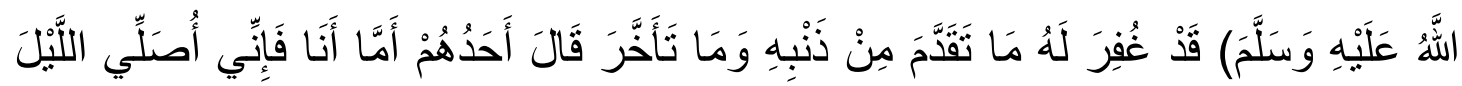

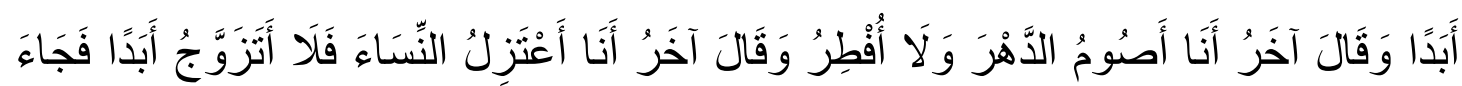

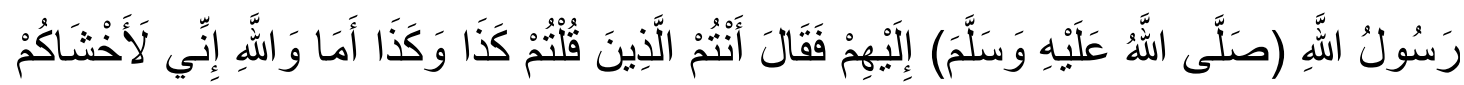

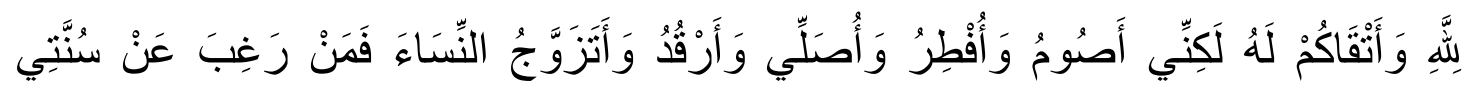

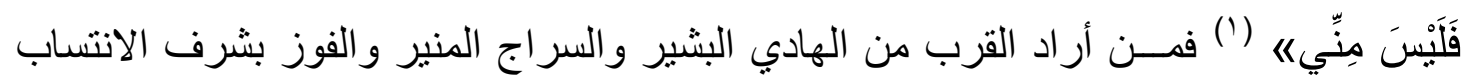
إليه فلا بد من الالتزام بهذه الوسطية وقد عقد النبي (صلى الله عليه وسلم) هذه الوسطية لاعَنْ

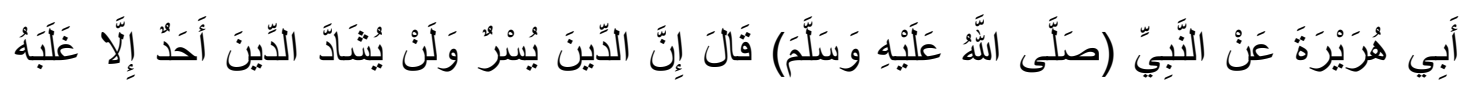

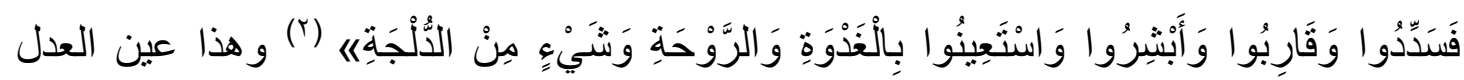
والاعندال والوسطية.

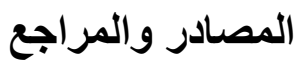

ا ـ الإتقان في علوم القرآن، السيوطي ( جلال الدين عبدالرحمن بن أبي بكر ) ت الإوهـ، ط:

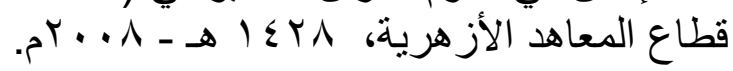

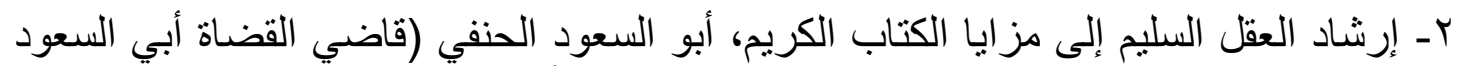

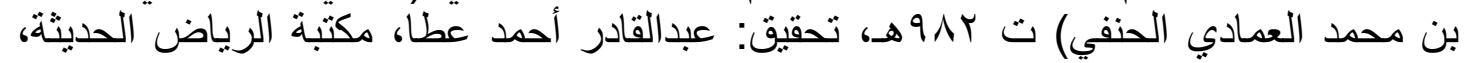

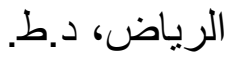

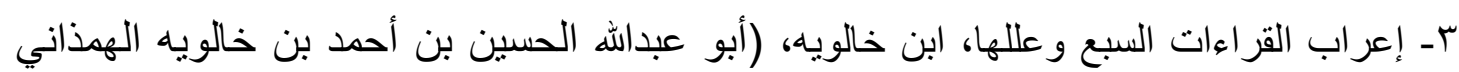

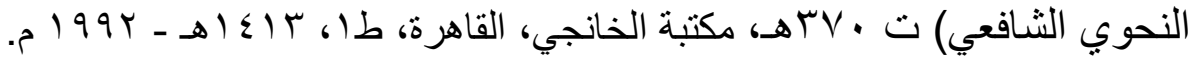

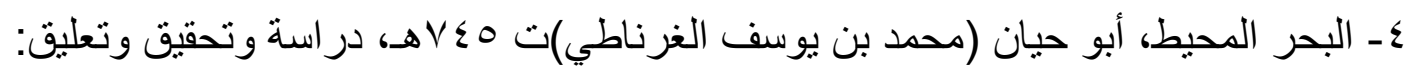

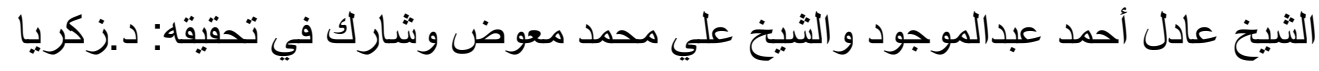

ا- صحيح البخاري (الجامع الصحيح المسند من حديث رسول الله - صلى الهـ عليه وسلم - وسننه و أيامه)

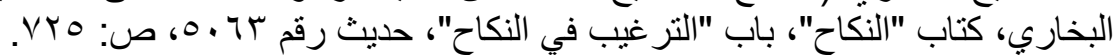

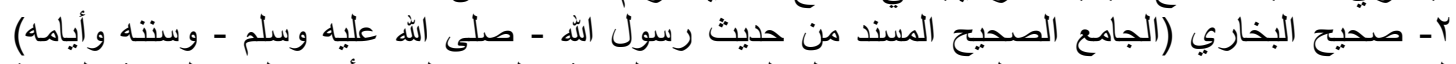
البخاري، كتاب "الإيمان"، باب "الدين يسر وقول النبي - صلى الله عليه وسلم ـ أحب الدين إلى الله الحنه الحنفية

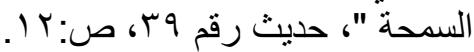


عبدالمجيد ود. أحمد النجولي الجمل وقرظه: أ.د.عبدالحي الفرماوي، دار الكتب العلمية، طا،

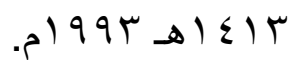

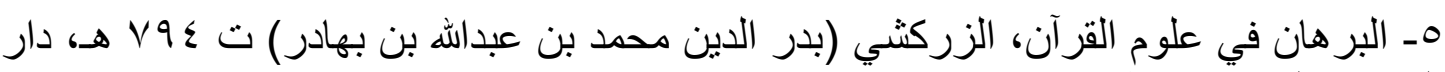
التراث، القاهرة، د.ط.

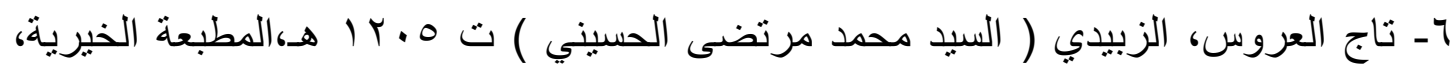
الجمالية، مصر، طاج الـ العروس

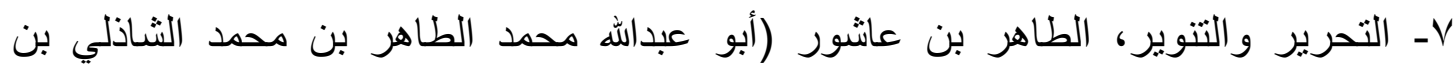

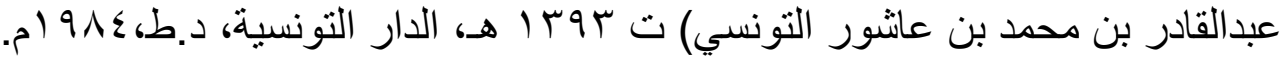

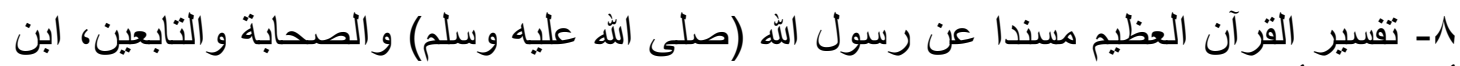

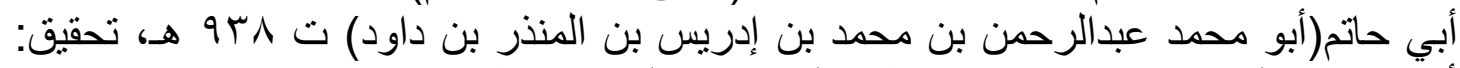

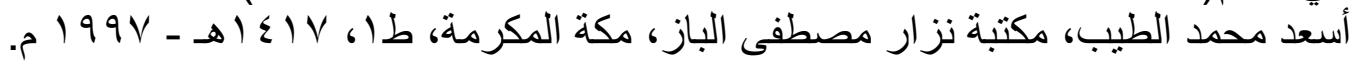

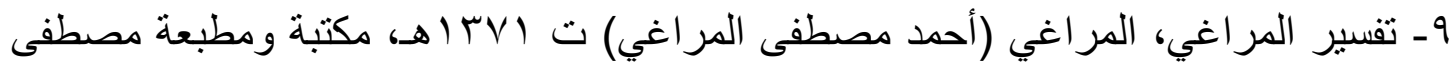
البابي الحلبي، مصر، طاغ طا،

• ا ـ الجامع لأحكام القرآن، القرطبي (أبي عبداله محمد بن أحمد بن أبي بكر) تحقيق: د.حامد

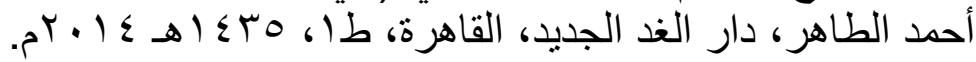

ا ا - جامع البيان عن تأويل آي القرآن، الطبري (أبو جعفر محمد بن جرير) الرسالة، بيروت،

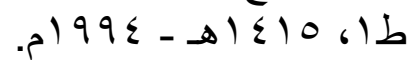

r إ- الجامع الصحيح المسند من حديث رسول الله (صلى الله عليه وسلم) وسننه وأيامه،

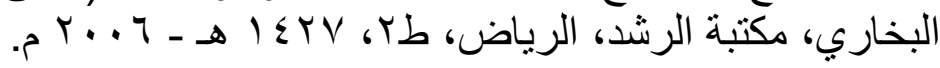

سا ــ الجواهر الحسان في تفسير القرآن، الثعالبي (عبدالرحمن بن محمد بن مخلوف) تحقيق

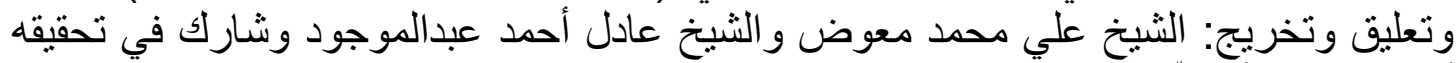

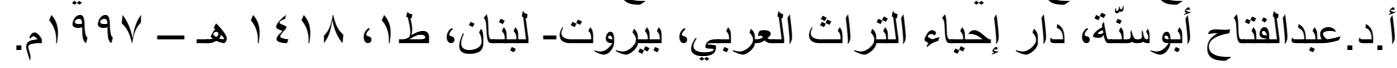

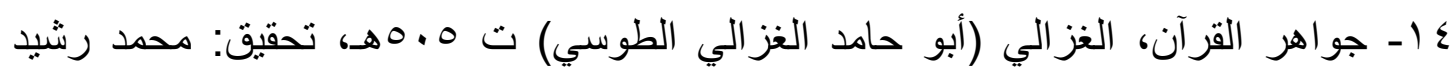

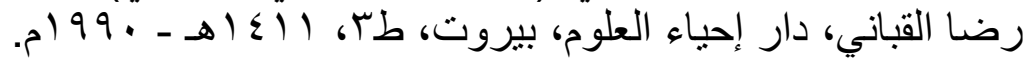

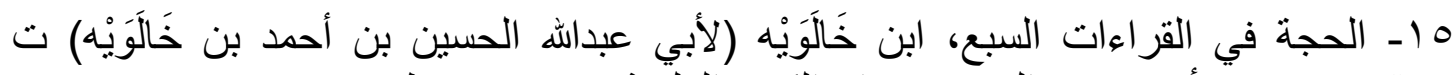

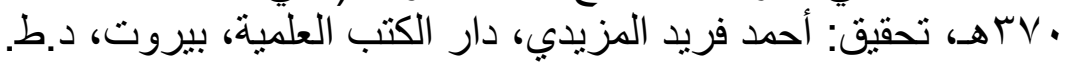

دا ـ الدر المصون في علوم الكتاب المكنون، السمين الحلبي، (أحمد بن يوسف) ت V07هـ، د. د.

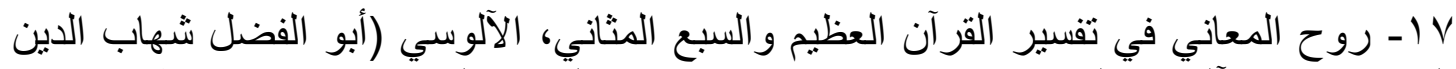

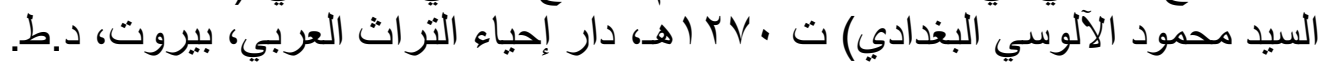


1 ا ـ سنن أبي داود، أبو داود(سليمان بن الأشعث السجستاني) ت

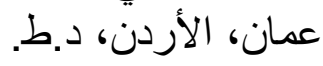

9 ا - سنن النسائي، النسائي(أبي عبدالرحمن أحمد بن شعيب بن علي) ت ب. باهـ، مكتبة

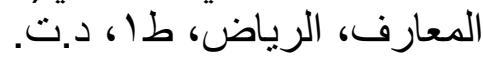

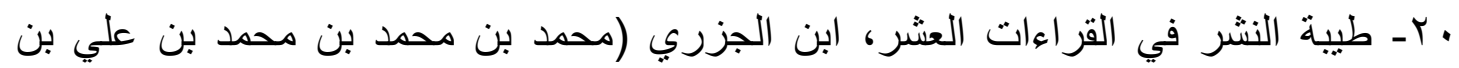

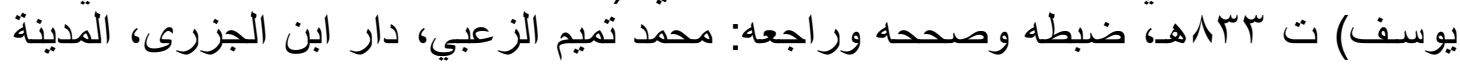

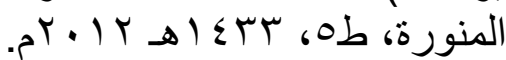

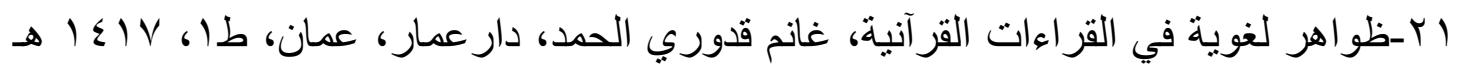

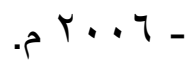

بr- غنية الطلبة بشرح الطيبة، الترمسي (محمد محفوظ بن عبداله) ت مبسا اهـ، تعليق:

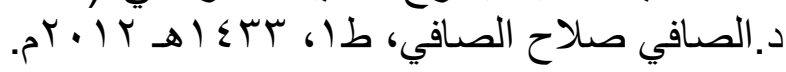

بr- غيث النفع في القراءات السبع، الصفاقسي(أبو الحسن علي بن سالم بن محمد) ت

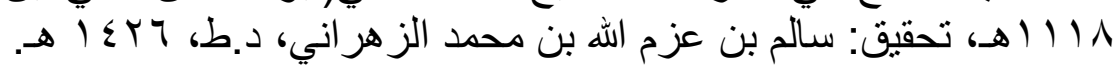

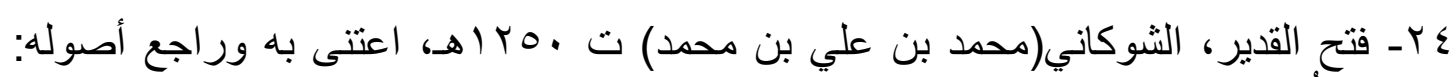

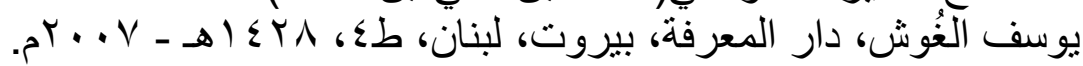

هو- القاموس المحيط، الفيروز آبادي(مجد الدين محمد بن بعقوب الفيروز آبادي) ت VIN Vه،

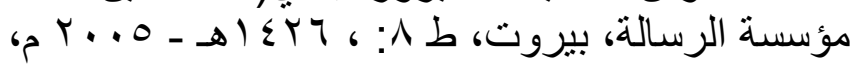

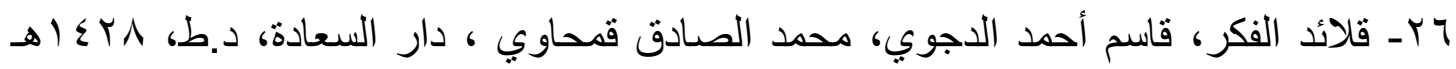
. . م

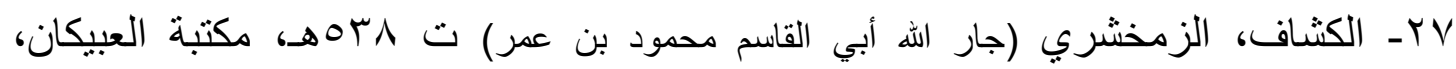

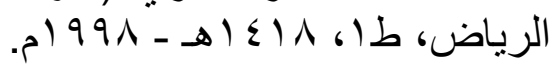

^ז - لسان العرب، ابن منظور( جمال الدين محمد بن مكرم ) ت / الVه، دار المعارف، د.ط.

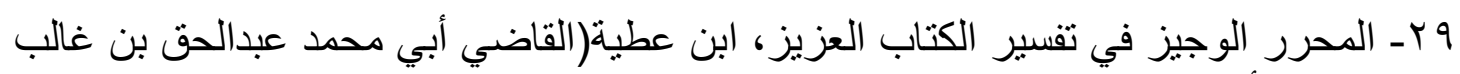
بن عطية الأندلسي) ت

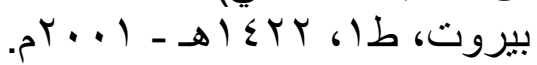

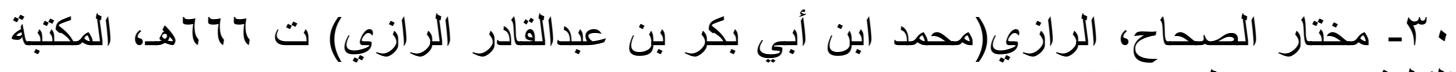

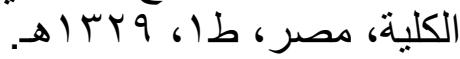


ابــ المسند الصحيح المختصر بنقل العدل عن العدل إلى رسول اله (صلى الله عليه وسلم)،

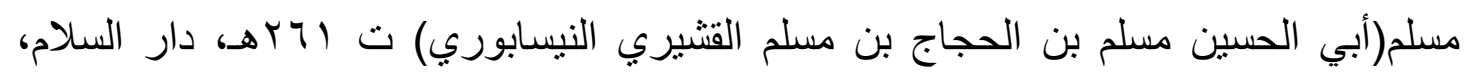

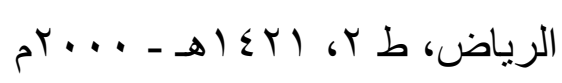

بr- مفاتيح الغيب، الرازي (محمد الرازي فخر الدين ابن العلامة ضياء الدين عمر المشتهر

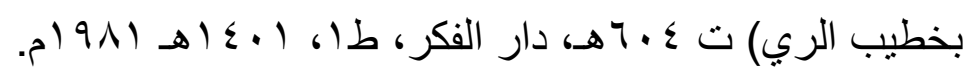

بr- الموطأ، الإمام مالك (مالك بن أنس بن مالك بن عامر) ت V9 اهـ، رواية: يحيى بن يحيى

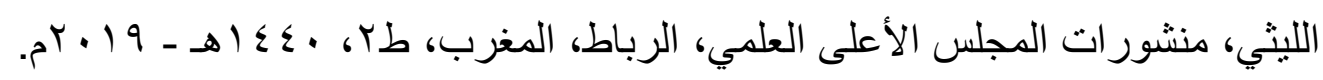

؟ ؟ـ- واقع الفتاوى المعاصرة في ضوء مقاصد الثريعة، زينب عبدالسلام أبو الفضل، دار

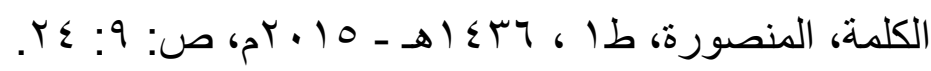

هr- ـ وسطية الإسلام وأمته في ضوء الفقه الحضاري، أ.عمر بهاء الدين الأميري، المركز

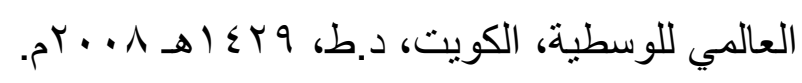

جسـ الوسطية الطريق إلى الغد، د.عبداله بن عبدالعزيز اليحيى، دار كنوز، الرياض، طا،

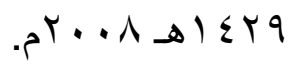

V V- الوسطية في الإسلام، فريد محمد هادي عبدالقادر، وهي رسالة ماجستير إثراف: د.

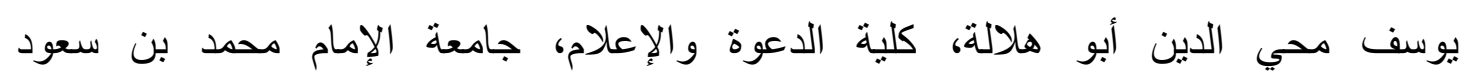

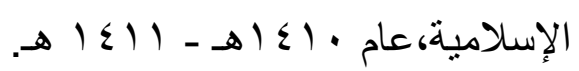

^rــ الوسطية و الاعتدال في التاريخ و التراث الإسلامي ( مجموعة مباحث تاريخية وثقافية حول التعايش الدذهبي في ضوء منهج الوحدة والتقريب القرآني ) علاء الدين المدرس، دار المأمون، د.ط.

9 بـ الوسطية ومظاهرها في القرآن الكريم، عصام صالح أحد راجح، رسالة ماجستير

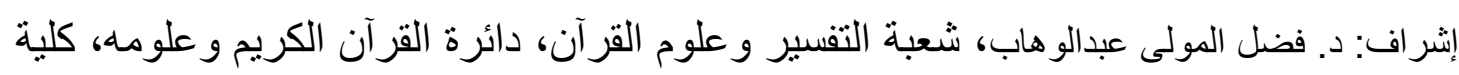

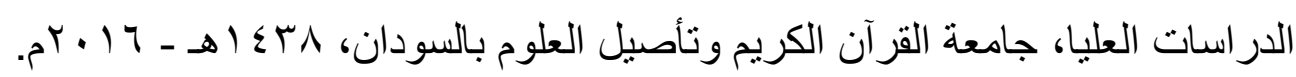




\title{
The Moderation
}

\author{
By \\ Ali Abdul galil El Saied El Shony \\ Islamic Studies Faculty of Arts, Tanta University
}

\author{
Prof. Dr. Amany Kamal Gharib \\ Professor of Islamic Studies Faculty of Arts, Tanta University.
}

\section{Dr.Rabie Mohammed Abdul Khaliq}

Rhetoric lecturer, Faculty of Arts, Tanta University.

\begin{abstract}
:
This research included the definition of moderation, And found in: the concepts, Such as: moderation in the concept of fighting, and moderation in the concept of money, and moderation in the concept of justice and the science of injustice, and moderation in the door of satisfaction, its features, importance, division, images, means of achieving its inclusion, obstacles to applying the central curriculum, reasons for people's distance from it, and the bad effects of distance from the central curriculum.

The middle is present in: grammar and fundamentals, Such as: the moderation of ijtihad, and the moderation of zaul Man, moderation in dealing with mistakes.

then the conclusion and includes references.
\end{abstract}

Keywords: Dictionaries, sections, means, fruits, obstacles 